\title{
Bibliography of Moraine Deposits in Denmark 1875-1974
}

Bibliografi over Moranedannelser i Danmark 1875-1974

$\mathrm{BY} / \mathrm{AF}$

IB MARCUSSEN

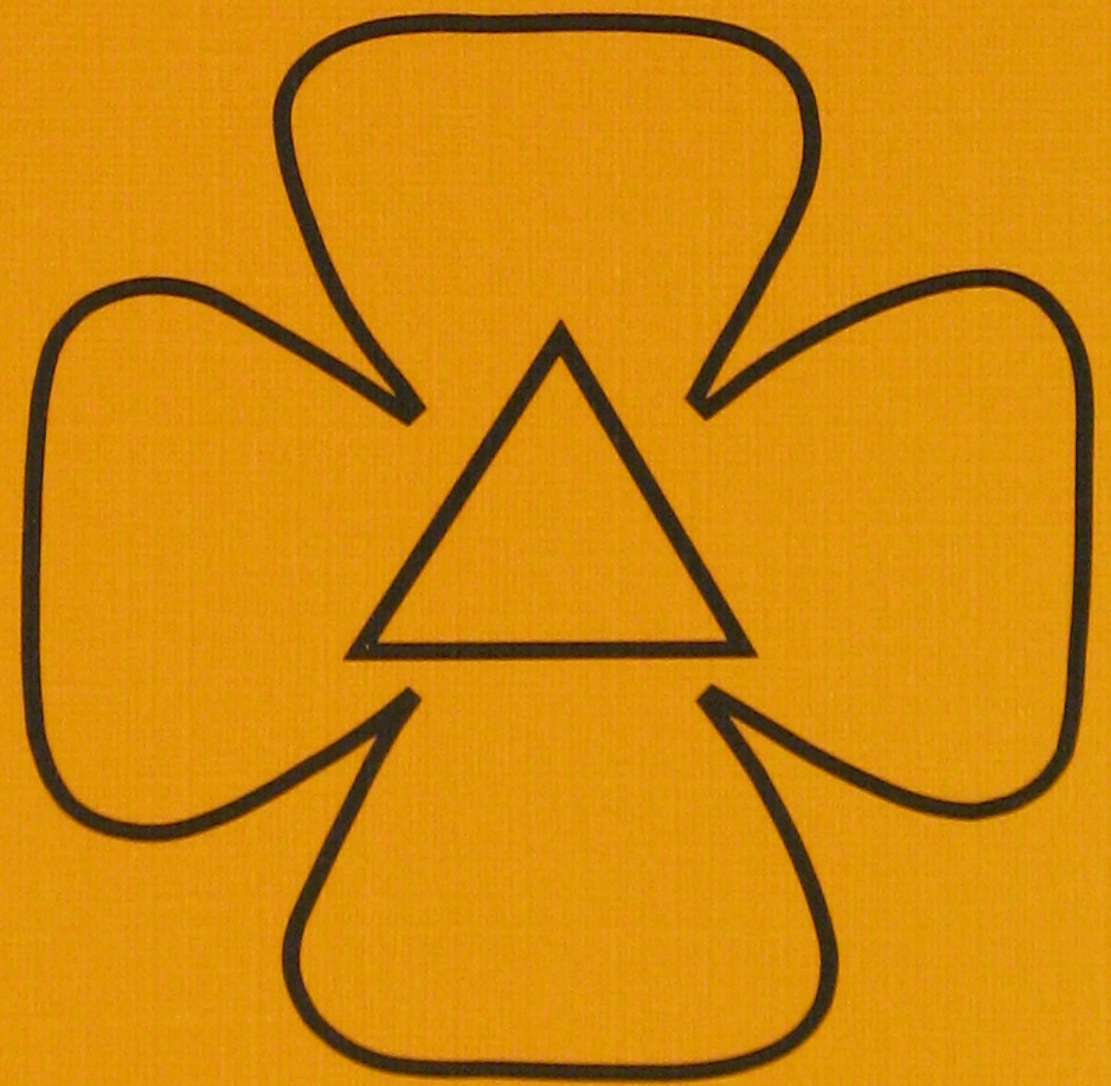

I kommission hos C. A. Reitzels Forlag · København 1986 


\section{Bibliography of Moraine Deposits in Denmark 1875-1974}

Bibliografi over Morcenedannelser i Danmark 1875-1974

BY/AF

IB MARCUSSEN 
Key-words:

Bibliography, Glacial deposition, Denmark

Vignette:

The four-leaf clover symbolizes the semantics of the term moraine: Morphology, Sediment, Lithostratigraphy and Genesis.

The triangle is the signature generally used for moraine.

Firkløveret symboliserer betydningsindholdet i ordet moræne: Morfologi, Sediment, Litostratigrafi og Genese.

Trekanten er den almindeligvis benyttede signatur for moræne.

DGU $\cdot$ serie B $\cdot$ nr. 9

ISBN 87-421-0740-7

ISSN 0901-0289

Oplag: 1200

Tryk: Aio Tryk as, Odense

Tegning: Henrik Klinge Pedersen

Dato: 1986-06-01

Ib Marcussen, Danmarks Geologiske Undersøgelse, Thoravej 31, DK-2400 København NV.

Redaktion: Knud Binzer

(C) Danmarks Geologiske Undersøgelse, Thoravej 31, DK-2400 København NV. 


\section{Contents}

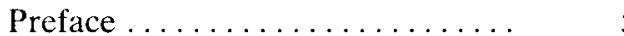

Introduction.............. 7

The indexes...............

Table of the subject index.......

The subject index............ 21

The authors index........... 53

\section{Indhold}

$5 \quad$ Forord $\ldots \ldots \ldots \ldots \ldots \ldots \ldots \ldots, 13$

$7 \quad$ Indledning .................... 15

$9 \quad$ Registrene................. 17

11 Oversigt over emneregisteret....... 19

$21 \quad$ Emneregisteret................ 21

$53 \quad$ Forfatterregisteret $\ldots \ldots \ldots \ldots \ldots, 53$ 



\section{Preface}

The literature on Quaternary glacigene deposits in Denmark is extensive, and it may easily involve a great deal of work to unearth the relevant material on a smaller region of Denmark or on a specific subject. It is therefore my hope that this bibliography will prove helpful to students in finding this type of literature and that it may serve as a guide to students interested in the history/ development of geology, helping them to understand the background for our present interpretation of the genesis and extension of the Quaternary glacial deposits in this country.

The bibliography was originally planned as part of a Nordic project. Thus the subject index was prepared in cooperation with colleagues from the other Nordic countries. Unfortunately, so many practical difficulties arose that the joint publication was abandoned. I wish to take this opportunity of thanking my colleagues for an inspiring collaboration, which due to external reasons did not lead to the result hoped for. Thanks to Jon Eiríksson (Iceland), Sylvi Haldorsen (Norway), Hans G. Johansson (Sweden) and Marjatta Perttunen (Finland).

To professor A. Dreimanis (Canada) I express my gratitude for many stimulating discussions concerning the subject index. 



\section{Introduction}

Unsorted or badly sorted sediments deposited by or in direct contact with glacier ice are called "moraine" in Danish. This term is used separately or in compound words for glacigene landforms as well as for lithostratigraphical units. Moraine has even have been used about non-glacial diamict sediments. This plural conception of the term is clearly disadvantageous for scientific use, but all four interpretations of the word are included in the bibliography. In 1972 the author proposed to use the term "till" in Danish for the glacigene sediments exclusively as it is done in American literature. The term till is presumably of Old Norse origin, and it is used frequently in modern Danish literature.

The year 1875 was chosen as the starting point for the bibliography because in that year professor Johnstrup at the University of Copenhagen published his thesis on the geognostic environment of Northern Jutland. Johnstrup discusses the unsorted boulder deposits and reaches the conclusion that they are deposited by glacier activity. Consequently it is the first true glacial-geological publication in Danish. 1875 was also the year that the Swedish geologist Otto Torell found striation on boulders in the vicinity of Berlin, Germany, and from this concluded that a large continuous ice sheet existed in Northern Europe during the Ice Age.

The bibliography contains a selection of references to literature on glacigene deposits in Denmark published 1875-1974. Only literature containing new and original observations or interpretations have been included.

Literature referring to former discoveries have not been included, as well as working papers, internal reports etc. which were specifically written for a very limited group of readers. However, in the library of the geological Survey of Denmark the complete bibliography can be consulted if the reader is interested in a complete moraine bibliography. Internal reports and the like are still not included. North Schleswig was part of Germany in a period before 1920 , but relevant literature from that period has been looked up.

The entries in the subject index have been made according to the author's interpretation of the observation described. Consequently it has not been taken into account that authors may have changed their opinion or that more recent investigations have shown that another interpretation is more probable.

The main sources of this bibliography are the publications from the Geological Society of Denmark and the Geological Survey of Denmark. A third important gateway to the literature has been the reference lists of the articles. Danish glacigene deposits have been described in publications from our neighbouring countries and to detect as many as possible the most relevant series have been searched systematically. The following sources have been used to prepare the bibliography:

Bibliographie der Zeitschriften des deutschen Sprachgebietes bis 1900. Vol. 1-3. Ed. J. Kirschner. Publ. 1966-1971.

Danmarks Geologiske undersøgelses skrifter 1890-1974.

Danske Blandede Tidsskrifter 1855-1912. København 1928-29. 
Dansk Bogfortegnelse 1869-1975. København.

Dansk Tidsskrift-Index 1915-1974. København 1916-1982.

Eiszeitalter und Gegenwart. Vol. 1-25. 1951-1974.

Gcografiska Annaler. Vol. 1-56A. 19191974.

Geologiska Föreningens i Stockholm Förhandlingar. 1875-1974.

Internationale Bibliographie der Zeitschriftenliteratur. Begründet 1898 von F. Dietrich. Fortgeführt von R. Dietrich. 18981964.

Meddelelser fra Dansk Geologisk Forening. 1894-1974. Including the registers for the years 1894-1920, 1921-1945, 1946-1960 prepared by Axel Garbo and the years 1966-1970 prepared by Erik Kristiansen, and the bibliography of the Dansk Geologisk Forening 1901-1968.

Norsk Geografisk Tidsskrift. Vol. 1-28. 1889-1974.

Norsk Geologisk Tidsskrift. Vol. 1-54. 1905-1974.

Schriften des Naturwissenschaftlichen Vereins für Schleswig-Holstein. Vol. 2-44. 1877-1974.
Articles containing summaries or abstracts in any other language than that of the title are marked with a capital letter at the end of the reference: $\mathrm{D}=$ Danish, $\mathrm{E}=$ English, $\mathrm{F}=$ French, and $\mathrm{G}=\mathrm{German}$.

The abbreviations of references are made according to the World List of Scientific Periodicals.

Zofia Orlowicz has typed the indexes and patiently altered, added and proof-read them several times. My warmest thanks for the good cooperation. Geologist Bent Søndergaard has drawn my attention to several publications. The librarians Erik Kristiansen, the Geological Museum, and Niels Toft Nielsen, the Geological Survey, have given constructive criticism to the manuscript. The staff of the Geological Survey of Denmark library has helped to find literature and has assisted with instructions and valuable advice during the work. Åge Nielsen and Stig Robertsen have assisted with the computer program, and Henrik Klinge Pedersen has drawn the Map. Niels Toft Nielsen and Birgit Jørgensen have corrected the English and the latter has typed the manuscript. To all I convey my sincere thanks. 


\section{The Indexes}

In the bibliography it is possible to search for articles either according to the subject of the articles or the author.

In the subject index the broad concept of moraine has been divided into 5 main groups. These groups are then further subdivided. The division appears from the outline on page 11. The subdivision of the country into regions is shown on the map (fig. 1).

In the authors index the references are arranged according to author. Within one author's work the references are arranged chronologically according to year of publication.

The number code at the end of the references indicates in which group in the Sub- ject Index the article can be found. The number code follows the division in the Subject Index (page 11).

In the references 3 types of editional remarks may appear in parantheses written in Danish.
A. "Påfølgende diskussion" means that the article is discussed in the references mentioned.
B. "Diskussion" means that the article is a contribution to a discussion. There might be references to other contribu- tions.
C. "Ekskursionsberetning" means excur- sion report.





\section{Table of the Subject Index}

1. Regional and stratigraphical

page descriptions .............. 21

1.1 Regional descriptions ........ 21

1.1.1 Northern Jylland...... 22

1.1.2 Central Jylland ....... 22

1.1.3 Southern Jylland . . . . . . 24

1.1 .4 Fyn ...................... 25

1.1.5 Sjælland ........... 26

1.1.6 Lolland-Falster ....... 27

1.1.7 Bornholm........... 27

1.2 Stratigraphical descriptions ... 28

2. Till genesis and till deposits...... 30

2.1 Lodgement till and melt-out till.................. 30

2.2 Ablation till ........... 30

2.3 Deformation till and glaciotectonic deformation........ 31

3. Morphology .............. 34

3.1 Ground moraine ......... 34

3.2 Ridges parallel to the ice movement............. 34
3.3 Ridges transverse to the ice

page movement............. 35

3.4 Formations of ablation...... 39

4. Till composition ............ 41

4.1 Texture .............. 41

4.1.1 Grain size composition . 41

4.1.2 Fabric, grain shape and roundness.......... 42

4.2 Structure .............. 42

4.3 Lithological composition .... 43

4.3.1 Fine material $(<2 \mathrm{~mm}) . \quad 44$

4.3.2 Coarse material (>2 mm) ......... 44

4.3.2.1 Stone countings. 45

4.3.2.2 Indicator boulder analysis 46

4.4 Geochemistry............ 48

4.5 Fossils . . . . . . . . . . . . . . . 49

5. Geotechnical and geophysical properties................. 51 



\section{Forord}

Litteraturen om kvartære glacigene aflejringer i Danmark er omfattende, og det kan ofte vare et stort arbejde at finde relevante artikler frem om egne eller bestemte emner. Det er derfor mit håb, at bibliografien vil være en hjælp ved litteratursøgning. Endvidere at den, der er interesseret i geologiens historie og udvikling, her kan fă hjælp til at finde baggrunden for vor nuværende tolkning af dannelsen og udbredelsen af kvartære aflejringer i Danmark.

Bibliografien blev oprindelig planlagt som en del af et nordisk projekt. Således er emneregisteret udarbejdet i samarbejde med kolleger fra de andre nordiske lande. Uheldigvis viste der sig så mange praktiske vanskeligheder, at en fælles publikation blev opgivet. Jeg ønsker at takke mine kolleger for et inspirerende samarbejde, som på grund af ydre vanskeligheder ikke førte til det resultat, vi havde håbet på. Takken skal gå til Jon Eiríksson (Island), Sylvi Haldorsen (Norge), Hans G. Johansson (Sverige) og Marjatta Perttunen (Finland).

Professor A. Dreimanis (Canada) ønsker jeg at takke for værdifulde diskussioner om emneregisteret. 



\section{Indledning}

Usorterede og dårligt sorterede sedimenter aflejret af eller i direkte kontakt med gletscheris kaldes på dansk moræne. Ordet bruges også alene eller i sammensatte ord for glacigene landskabsformer og for litostratigrafiske emheder. Moræne er endog tillige brugt om non-glaciale, diamikte sedimenter. Dette flertydige indhold i ordet er selvsagt uhensigtsmæssig til videnskabelig brug, men i bibliografien er alle fire betydninger medtaget. Det har tidligere (1972) været foreslået af forfatteren, at ordet "till" kunne benyttes på dansk for glacigene sedimenter, på samme måde som det bruges i amerikansk litteratur. Ordet till er formodentlig af oldnordisk oprindelse, og det benyttes hyppigt i nyere dansk litteratur.

Som begyndelsesår for bibliografien blev 1875 valgt. Det var det år, professor Johnstrup ved Københavns Universitet publicerede sin afhandling om de geognostiske forhold i Nordjylland. I afhandlingen diskuterer Johnstrup rullestenslerets dannelse, og når til den konklusion, at det er afsat af en gletscheris. Afhandlingen bliver således den forste egentlige glacial-geologiske på dansk . 1875 var også det år, den svenske geolog Otto Torell fandt skurestriber på sten ved Berlin og deraf drog den slutning, at hele Nordeuropa havde været dækket af et sammenhængende isskjold $\mathrm{i}$ istiden.

Bibliografien består af udvalgte referencer af litteraturen om glacigene aflejringer publiceret mellem 1875 og 1974. Kun litteratur, der indeholder nye og originale observationer eller tolkninger, er taget med. Litteratur, der refererer til tidligere publicerede iagttagelser og tolkninger, er ikke medtaget, ligesom interne rapporter og lignende afhandlinger, der henvender sig til en begrænset gruppe læsere. Læsere, der er interesseret $\mathrm{i}$ den mere omfattende bibliografi, vil på Danmarks Geologiske Undersøgelses bibliotek kunne benytte den samlede bibliografi. Heri er dog heller ikke medtaget rapporter og lignende. Nordslesvig var en del af Tyskland før 1920, men litteratur fra perioden er medtaget $\mathrm{i}$ bibliografien.

I emneregisteret er den enkelte afhandling opført i den eller de emnegrupper, som passer med indholdet, og som er i overensstemmelse med forfatterens tolkning af de beskrevne iagttagelser. Der er således ikke taget hensyn til, at forfatteren måske senere har ændret synspunkt, eller at forskningen har vist, at en anden tolkning er mere sandsynlig.

Hovedkilderne til bibliografien har været publikationerne fra Dansk Geologisk Forening og Danmarks Geologiske Unders $\emptyset$ gelse. En tredje vigtig indgang til litteraturen er referencelisterne $\mathrm{i}$ afhandlingerne. Danske glacigene aflejringer er også beskrevet i publikationer fra vore nabolande, og for at finde så mange som muligt er flere serier gennemgået systematisk. Følgende kildemateriale har været benyttet:

Bibliographie der Zeitschriften des deutschen Sprachgebietes bis 1900. Bd. 1-3. Ed. J. Kirschner. udg. 1966-71.

Danmarks Geologiske Undersøgelses skrifter 1890-1974.

Danske Blandede Tidsskrifter 1855-1912. København 1928-29.

Dansk Bogfortegnelse 1869-1975. København.

Dansk Tidsskrift-Index 1915-1974. København 1916-1982. 
Eiszeitalter und Gegenwart. Bd. 1-25. 1951-1974.

Geografiska Annaler. Bd. 1-56A. 19191974.

Geologiska Föreningens i Stockholm Förhandlingar. 1875-1974.

Internationale Bibliographie der Zeitschriftenliteratur. Begründet 1898 von F. Dietrich. Fortgeführt von R. Dietrich. 18981964.

Meddelelser fra Dansk Geologisk Forening. 1894-1974. Herunder generalregistrene 1894-1920, 1921-1945, 1946-1960 ved Axel Garbo og 1966-1970 ved Erik Kristiansen, samt Dansk Geologisk Forenings litteraturfortegnelser, 1901-1968.

Norsk Geografisk Tidsskrift. Bd. 1-28. 1889-1974.

Norsk Geologisk Tidsskrift. Bd. 1-54. 1905-1974.

Schriften des Naturwissenschaftlichen Vercins für Schleswig-Holstein. bd. 2-44. 1877-1974.

Safremt afhandlingerne har en sammenfatning eller tilsvarende på et andet sprog, end det sprog de er skrevet på, er det angivet sidst i referencen med et stort bogstav efter følgende regel: $\mathrm{D}=$ dansk, $\mathrm{E}=$ engelsk, $F=$ fransk og $G=$ tysk.

Forkortelserne af referencerne er foretaget $\mathrm{i}$ overensstemmelse med World list of Scientific periodicals.

Zofia Orlowicz har skrevet referencerne og tălmodigt ændret, tilføjet og korrekturliest dem adskillige gange. Jeg ønsker at udtrykke min varmeste tak for det gode samarbejde. Geolog Bent Søndergaard har bidraget med henvisninger til afhandlinger. Bibliotekarerne Erik Kristiansen, Geologisk Museum, og Niels Toft Nielsen, Danmarks Geologiske Unders $\emptyset$ gelse, har efter kritisk gennemlæsning af manuskriptet givet konstruktive råd. Personalet på DGU's bibliotek har hjulpet med at finde litteratur frem, og givet værdifulde instruktioner og răd under arbejdet. Åge Nielsen og Stig Robertsen har assisteret ved brugen af computer-programmet, og Henrik Klinge Pedersen har tegnet kortet. Niels Toft Nielsen og Birgit Jørgensen har korrigeret det engelske manuskript, og Birgit Jørgensen har renskrevet afhandlingen. Min hjerteligste tak til alle. 


\section{Registrene}

Bibliografien er udformet således, at artikler kan søges enten efter emne eller efter forfatter.

I emneregisteret er det brede begreb moræne opdelt i 5 hovedgrupper, som derefter er underinddelt. Inddelingen fremgår af oversigten side 19. Den regionale opdeling af landet fremgår af fig. 1 .
I forfatterregisteret er artiklerne ordnet efter forfatter og årstal. Det er tillige angivet med en nummer kode $i$ hvilket eller hvilke afsnit $\mathrm{i}$ emneregisteret den pågældende afhandling også kan findes. Nummerkoderne fremgår af oversigten side 19 . 



\section{Oversigt over emneregister}

side

1. Regionale og stratigrafiske beskrivelser ................. 21

1.1 Regionale beskrivelser ...... 21

1.1.1 Nordjylland ......... 22

1.1.2 Midtjylland .......... 22

1.1.3 Syd- og Sønderjylland .. 24

1.1.4 Fyn ............... 25

1.1.5 Sjælland .......... 26

1.1.6 Lolland-Falster ....... 27

1.1.7 Bornholm........... 27

1.2 Stratigrafiske beskrivelser .... 28

2. Tilldannelse og tillaflejringer..... 30

2.1 Bundtill og udsmeltningstill... 30

2.2 Ablationstill ............ 30

2.3 Deformationstill og glacial tektonik................ 31

3. Morfologi............... 34

3.1 Bundmoræne ............ 34

3.2 Rygge parallel med isbevægelsen............. 34

3.3 Rygge på tværs af isbevægelsen............ 35

3.4 Afsætninger af

side ablationsmoræne .......... 39

4. Tillsammensatning .......... 41

4.1 Textur ............... 41

4.1.1 Kornstørrelses sammensætning ...... 41

4.1.2 Fabric, korn form og afrundethed ........ 42

4.2 Strukturer.............. 42

4.3 Litologisk sammensætning.... 43

4.3.1 Finet materiale $(<2 \mathrm{~mm}) \ldots \ldots \ldots \ldots \quad 44$

4.3.2 Groft materiale $(>2 \mathrm{~mm}) \ldots \ldots \ldots \ldots \quad 44$

4.3.2.1 Stentællinger ... 45

4.3.2.2 Ledebloks analyser ..... 46

4.4 Geokemi............. 48

4.5 Fossiler ............... 49

5. Geotekniske og geofysiske forhold. 51 


\section{Subject index \\ Emneregister}

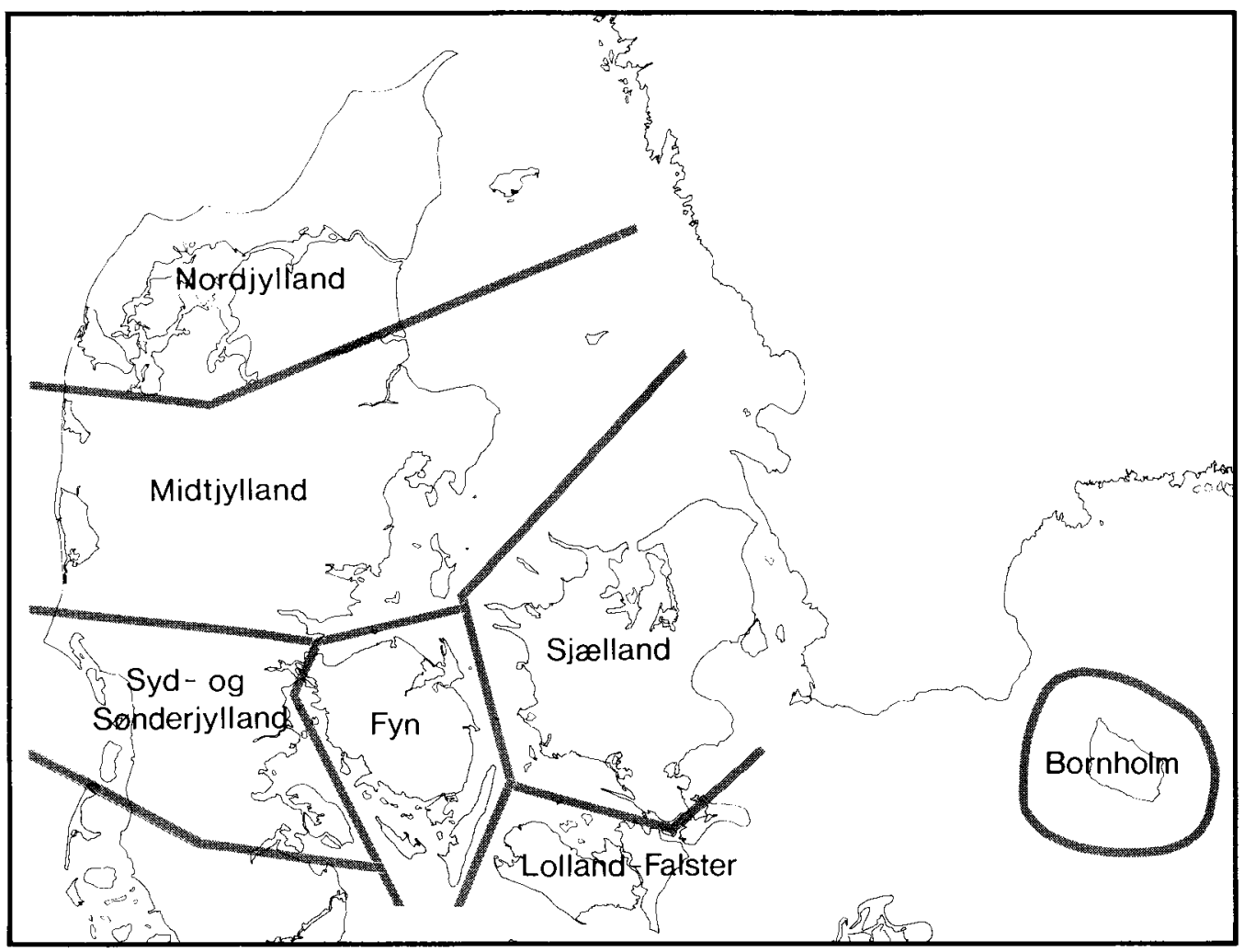

Fig. 1. The map indicates the subdivision of the country in the regions used in the subject index. Kortet angiver den inddeling $i$ regioner, der benyttes $i$ emneregistret. 


\section{Regional and stratigraphical descriptions Regionale og stratigrafiske beskrivelser}

\section{Regional descriptions \\ Regionale beskrivelser}

Andersen, S. A.

Det danske Landskabs Historie.

København, 275p

Andersen, S. A.

En fremstilling af Danmarks Kvartærgeologi.

(Diskussion. Se Hansen, S. 1965 og 1966)

Meddr dansk geol. Foren., 16, 214-229 og 232-233

Bornebusch, C. H. og. K. Milthers

1935

Jordbundskort over Danmark.

Danm geol. Unders., III, 24 (E)

Gripp, K.

1967

Der Abbau des würmzeitlichen Eises im

Bereich des Kattegat.

Meddr dansk geol. Foren., 17, 58-75 (E)

Hansen, S.

1965

The Quaternary of Denmark.

(Påfølgende diskussion se Andersen, S,

A. 1966 og Hansen, S. 1966)

Rankama, K. (ed.), The geologic systems, 1, New York. 1-90

Hansen, $\mathrm{S}$.

1966

Bemærkninger til hr. S. A. Andersens kritiske anmeldelse af "The Quaternary of Denmark".

(Diskussion. Se Andersen, S. A. 1966 og Hansen, S. 1965)

Meddr dansk geol. Foren., 16, 230-232

Jessen, A.

Kortbladene Læs $\emptyset$ og Anholt.

Danm. geol. Unders., I, 4, 48p (F)

Milthers, K.

Ledeblokke og Landskabsformer i Danmark.
(Påfølgende diskussion se Andersen, S.

A. 1945 og Milthers, K. 1945)

Danm. geol. Unders., II, 69, 137p (E)

Milthers, $\mathrm{K}$.

1945

Danmarks Overflade dannes.

Danmark, 1-10

Milthers, $\mathrm{V}$

Israndens Tilbagerykning fra $\emptyset$ stjylland til Sjælland-Fyn, belyst ved Ledeblokke.

(Påfølgende diskussion se Madsen, V . 1931 og Milthers, V. 1931)

Meddr dansk geol. Foren., 8, 1-70

Samme udgivet 1932 i Danm. geol. Unders., IV, 2, 9, 70p (G)

Milthers, V.

Betydningsfulde Forekomster af Basaltblokke i Jylland.

Meddr dansk geol. Foren., 7, 309-316

Milthers, $\mathrm{V}$.

1948

Det danske Istidslandskabs Terrænformer og deres Opstaaen.

Danm. geol. Unders., III, 28, 233p (E)

Nordmann, V. (ed.) 1928

Oversigt over Danmarks Geologi.

Danm. geol. Unders., V, 4, $208 p(E / F / G)$

Rørdam, K.

1909

Geologi og Jordbundslære.

3 bd, København

Ussing, N. V.

1903

Om Jyllands Hedesletter og Teorierne for deres Dannelse.

K. danske Vidensk. Selsk. Skr., 2, 99165 (F)

Ussing, N. V.

1903

Geologi og Overflade forhold.

I: J. P. Trap, Kongeriget Danmark, 1, 3-22. København. 
Ussing, N. V.

1907

Om Floddale og Randmoræner i Jylland.

K. danske Vidensk. Selsk. Skr., 4, 160$213(\mathrm{~F})$

Ussing, N. V.

Danmarks Geologi i almenfatteligt omrids. 3. Ed.

Danm. geol. Unders., III, 2, 372p

Wennberg, G.

1943

Eisströme über Schönen während der letzten Eiszeit.

Acta Univ. lund, NF, avd. 2, 39, 3, 28p

Werth, E.

1907

Dänemark und die Eiszeit.

Aus der Natur, 1-5

\section{Northern Jylland}

Nordjylland

Andersen, S. A.

1946

Hvorledes Landet blev til.

Brunsgaard, C. og H. E. Pedersen(eds.), Landet mod nordvest-Thy og Vester Han Herred, København. Bd. 1, 7-32

Andersen, S. A. 1961

Geologisk fører over Vendsyssel.

København, 207p.

Andersen, S. A.

Isens bortsmeltning i Limfjordsegnen.

(Diskussion. Se Gripp, K. 1966 og 1967)

Meddr dansk geol. Foren., 17, 138$144(\mathrm{G})$

Gripp, K.

1966

Die Eisrandkerbe von Himmerland und der Abbau des würmzeitlichen Eises im Bereich des Limfjordes.

(Påfø̆lgende diskussion se Andersen, S.

A. 1967 og Gripp, K. 1967)

Meddr dansk geol. Foren., 16, 138-152

Gripp, K. 1967

Ueber den Wert von S. A. Andersen's Kritik.

(Diskussion. Se Andersen, S. A. 1967 og

Gripp, K. 1966)

Meddr dansk geol. Foren., 17, 144-145

Gry, $\mathrm{H}$.

1940

De istektoniske Forhold i Molerområdet.
Meddr dansk geol. Foren., 9, 586-627

Jessen, A.

Kortbladene Skagen, Hirshals, Frederikshavn, Hjøring og Løkken.

Danm. geol. Unders., 1, 3, 368p (F)

Jessen, A.

1905

Kortbladene Aalborg og Nibe (nordlige

Del).

Danm. geol. Unders., I, 10, 193p (F)

Jessen, A.

1936

Vendsyssels Geologi.

Danm. geol. Unders., V, 2, 195p

Johnstrup, F.

1882

Om de geologiske Forhold i den nordlige

Del af Vendsyssel.

Indbydelsesskrift til Universitets Aarsfest, København, 1-43

Milthers, V.

1907

Vendsyssels ældre Yoldialer og den glaciale Lagfølge i Jylland.

Meddr dansk geol. Foren., 3, 1-12

Milthers, V.

1914

Mergel og Kalk i det nordvestlige Jylland.

Danm. geol. Unders., III, 11, 24p

Petersen, F. Schausen

1958

Landskabet.

Huhle, R. (ed.), Bogen om Himmerland, Aabenraa. 7-43

\section{Central Jylland}

Midtjylland

Andersen, H. Lykke

1968

Træk af Jelshøj-buernes udviklingshistorie.

Meddr dansk geol. Foren., 18, 137-140

Andersen, H. Lykke

1973

En begravet dal i Præ-Kvartæret ved Århus.

Dansk geol. Foren. Årsskrift 1972, 111118

Andersen, S. A.

1965

Isens bortsmeltning $\mathrm{i}$ egnen mellem $\mathrm{Vi}$ borg og Grenå.

(Diskussion. Se Gripp, K. 1964 og 1965)

Meddr dansk geol. Foren., 15, 589-595, 596-597 (G) 
Andersen, S. A.

1968

Ekskursion fra Århus gennem terrænet vest for byen.

Meddr dansk geol. Foren., 18, 130-132

Berthelsen, A.

Nogle ledebloktællinger på Horsensegnen.

Meddr dansk geol. Foren., 11, 449455 (E)

Gripp, K.

1964

Der Verlauf der Eisrandlagen zwischen Grenaa und Viborg.

(Păfølgende diskussion se Andersen, S.

A. 1965 og Gripp, K. 1965)

Meddr dansk geol. Foren., 15, 346-358

Gripp, K.

1965

Antwort an Herrn S. A. Andersen.

(Diskussion. Se Andersen S, A. 1965 og Gripp, K. 1964)

Meddr dansk geol. Foren., 15, 595-596

Gripp, K.

1966

Die Eisrandkerbe von Himmerland und der Abbau des würmzeitlichen Eises im Bereich des Limfjordes.

(Se Andersen, S. A. 1967 og Gripp, K. 1967)

Meddr dansk geol. Foren., 16, 138-152

Hansen, K.

1958

Landskabsudviklingen i Himmelbjergegnen.

Meddr dansk geol. Foren., 13, 542-545

Hansen, V.

1943

Østjylland - en geografisk Provins.

Geogr. Tidsskr., 46, 72-90

Harder, P.

1908

En østjydsk Israndslinie.

Danm. geol. Unders., II, 19, 259p (E)

Jessen, A.

Kortbladene Læsø og Anholt.

Danm. geol. Unders., 1, 4, 48p (F)

Jessen, A.

1922

Kortbladet Varde.

Danm. geol. Unders., I, 14, 105p (F)

Jessen, A.

Kortbladet Blaavandshuk.

Danm. geol. Unders., I, 16, 76p (F)
Liboriussen, $\mathbf{J}$.

1972

Fabric-studier af smeltevandsgrus og moræneler $\mathrm{i}$ den nordlige del af kortbladet Randers.

Dansk geol. Foren. Årsskrift 1971, 31-35

Madsen, V.

1897

Kortbladet Samsø.

Danm. geol. Unders., I, 5, 87p (F)

Madsen, $V$.

1921

Terrainformerne paa Skovbjerg Bakkeø.

Danm. geol. Unders., IV, 1, 12, 24p (F)

Madsen, V.

1931

Ledeblokke og Israndsstadier i det centrale Danmark.

(Diskussion. Se Milthers, V. 1931 og 1931)

Meddr dansk geol. Foren., 8, 140-141

Milthers, K.

1935

Landskabets Udformning mellem Alheden og Limfjorden.

Danm. geol. Unders., II, 56, 36p (G)

Milthers, K.

Systematisk Eftersøgning af Brunkul.

Geogr. Tidsskr., 44, 100-117

Milthers, $\mathrm{K}$.

1942

Erosionsformer i Midtjyllands Tertiæroverflade.

Meddr dansk geol. Foren., 10, 101-107

Milthers, V.

1916

Mergelaflejringerne i Hammerum Herred.

Danm. geol. Unders., III, 13, 21p

Milthers, V.

1917

Mergelen i Holstebro Egnen.

Danm. geol. Unders., III, 15, 18p

Milthers, V.

1919

Mergelen i Djursland.

Danm. geol. Unders., III, 18, 41p

Milthers, V.

Jordbundsforholdene omkring Overlund ved Viborg.

Danm. geol. Unders., III, 19, 20p

Milthers, V.

1925

Kortbladet Bække.

Danm. geol. Unders., I, 15, 175p (F)

Milthers, V.

Ledeblokke og Israndsstadier i det centrale Danmark. 
(Diskussion. Se Madsen, V. 1931 og Milthers, V. 1931)

Meddr dansk geol. Foren., 8, 139-142

Milthers, V.

Kortbladet Brande.

Danm. geol. Unders., I, 18, 162p (F)

Milthers, V.

Et vestjysk istidsområde.

Meddr dansk geol. Foren., 13, 61-78

Milthers, V.

Sydvestjyllands glaciale lagforhold.

Meddr dansk geol. Foren., 13, 206$216(\mathrm{E})$

Milthers, V. og Th. Claudi Westh 1913

Viborg Egnens Mergellag, deres geologiske Omgivelser og deres Udnyttelse.

Danm. geol. Unders., III, 9, 70p

Møller, M.

Fra Aarhus-Dalen til Horsens Fjord.

Meddr dansk geol. Foren., 7, 151-164

Nielsen, O. Bjørslev

1973

Eocæne aflejringer i Ølst-området og deres indpasning i områdets kvartærgeologi. Dansk geol. Foren. Årsskrift 1972, 100110

Nordmann, V.

1927

Israndslinier paa Kortbladet "Fredericia".

Meddr dansk geol. Foren., 7, 171-175

Nordmann, V.

1928

Ekskursion til Vejle-Fredericia egnen.

(Ekskursionsberetning)

Meddr dansk geol. Foren., 7, 239-246

Nordmann, $\mathrm{V}$.

1958

Kortbladet Fredericia.

A: Kvartære aflejringer.

Danm. geol. Unders., I, 22A, 125p (E)

$\varnothing$ dum, $H$.

1969

Kvartæret omkring Hobro.

Danm. geol. Unders., IV , 4, 10, 23p (G)

\section{Southern Jylland}

Syd-og Sønderjylland

Eggers, W.

1930

Geomorphologische Übersichtskarte von

Schleswig.

Schleswig-Holsteinische Uni.ges.sch, 25, 1
Haas, $\mathrm{H}$.

1889

Die geologische Bodenbeschaffenheit

Schleswig-Holsteins. Kiel und Leipzig, $152 \mathrm{p}$

Hansen, S.

1965

Kortbladet Tinglev.

Danm. geol. Unders., I, 23 (2 kort, Teksten er ikke udgivet).

Hansen, S., V. Nordmann og

1947

Th. Sorgenfrei

Ekskursion til Nordslesvig.

(Ekskursionsberetning)

Meddr dansk geol. Foren., 11, 229-236

Hansen, V.

1943

Østjylland - en geografisk Provins.

Geogr. Tidsskr., 46, 72-90

Jessen, A.

1907

Kortbladet Skamlingsbanke.

Danm. geol. Unders., I, 12, 99p (F)

Jessen, A.

1935

Kortbladet Haderslev.

Danm. geol. Unders., I, 17, 95p (F)

Jessen, A.

1935

Geologisk Kort over Sønderjylland

1: 125000 .

Danm. geol. Unders., Kort og tekst.

Jessen, A.

1945

Kortbladet Sønderborg.

Danm. geol. Unders., I, 20, 91p (F)

Meyn, L.

1881

Geologische-Uebersichtskarte der Provinz Schleswig-Holstein. 1: 300000

K. Preuss. geologischen Landesanstalt

Nordmann, $\mathrm{V}$.

1935

De geologiske Forhold langs Kongeaadalen.

Historisk Samfund for Ribe amt, 8, 597616

Nordmann, V.

1943

Tønder gennem Tiderne.

Historisk Samfund for Sønderjylland, 3, $7-31$

Struck, R.

1909

Übersicht der geologischen Verhältnisse Schleswig-Holsteins.

Festschrift zur Begrüssung, des 17. Deutschen Geographentages. Lübeck, 169p. 
Die Oberflächenformen Schleswig-Holsteins und ihre Entstehung.

Lübeck. 31p

Sørensen, R. P.

Landskabsformer.

I: Sørensen, R. P. (ed.), Bogen om Bov Sogn, skrevet af Mænd i Sognet. Padborg. 7-27

Sørensen, R. P.

1963

Sønderjyske Landskaber.

Faglig Læsning, 48, København. 32p.

Woldstedt, P.

Beiträge zur Morphologie von Nordschleswig.

Mitt. geogr. Ges. naturh. Mus. Lübeck, $2,26,1-70$

Woldstedt, P.

Probleme der Seenbildung in Norddeutschland.

Zeit. Gesell. Erdkunde, Berlin, 103-124

Woldstedt, P.

1930

Die Gliederung des Nordeuropäischen Diluviums.

Nordmann, V (ed), Compte Rendu de la Réunion géologique internationale a Copenhague 1928.

Danm geol. Unders, 209-224

Woldstedt, P.

Geologisch-morphologischen Übersichtskarte des norddeutschen Vereisungsgebietes. 1: 1. 500000 .

Preuss. geologischen Landesanstalt. Kort og tekst.

Wolf, W.

Erdgeschichte und Bodenaufbau Schleswig-Holsteins.

Hamburg 163p.

Wolf, W. und H-L. Heck

Erdgeschichte und

1949

Schleswig-Holsteins.

Hamburg 194p.

Ødum, $\mathrm{H}$.

Bemærkninger om Vestgrænsen for den sidste Nedisning i Nordslesvig.

Meddr dansk geol. Foren., 7, 170-171

Ødum, H.

Jordlag og Landskabsformer.

Clausen, H. V. og H. Ødum (eds), Nordslesvig, Min Hjemstavn, nr. 10, 1 -18, København.

Fyn

Fyn

Andersen, S. A.

1963

Om Fyens glaciale terrænformer og deres opståen.

(Diskussion. Se Smed, P. 1962 og 1963)

Meddr dansk geol. Foren., 15, 223-228

Grönwall, K. A.

1904

Forsteningsførende Blokke fra Langeland, Sydfyn og Ærø samt Bemærkninger om de ældre Tertiærdannelser i det baltiske Område.

Danm. geol. Unders., II, 15, 62p (F)

Madsen, V.

1900

Kortbladet Bogense.

Danm. geol. Unders., I, 7, 112p (F)

Madsen, V.

1902

Kortbladet Nyborg.

Danm. geol. Unders., I, 9, 182p (F)

Madsen, $V$.

Om den glaciale, isdæmmede S $\emptyset$ ved Stenstrup paa Fyn samt om Dannelsen af Teglværksleret i Stenstrup-Egnen.

Danm. geol. Unders., II, 14, 86p (F)

Milthers, K.

Kortbladene Fåborg, Svendborg og Gulstav.

A: Kvartære aflejringer.

Danm. geol. Unders., I, 21A, 112p (E)

Milthers, V.

1928

Glacialgeologiske Retningslinjer i

Odense Egnen.

Danm. geol. Unders., IV, 2, 4, 24p

Milthers, V.

Kortbladet Vissenbjærg.

Danm. geol. Unders., 1, 19, 143p (F)

Nielsen, A. V.

1961

Lind $\emptyset$, et af Keld Milthers sidste kvartærgeologiske arbejdsfelter.

Meddr dansk geol. Foren., 14, 453-454 
Smed, P.

1962

Studier over den fynske $\emptyset$ gruppes glaciale landskabsformer.

(Påfølgende diskussion se Andersen, S.

A. 1963 og Smed, P 1963)

Meddr dansk geol. Foren., 15, 1-74 (E)

Smed, P.

1963

Gensvar til S. A. Andersen.

(Diskussion. Se Andersen, S. A. 1963 og Smed, P. 1962)

Meddr dansk geol. Foren., 15, 228-229

Ussing, N. V. og V. Madsen

1897

Kortbladet Hindsholm.

Danm. geol. Unders., I, 2, 87p (F)

Wennberg, G.

Differentialrörelser i Inlandsisen.

Sista Istiden i Danmark, Skåne och Östersjön.

Meddn Lunds geol.-min. Instn., 114, $201 \mathrm{p}$

\section{Sjaclland}

Sjalland

Andersen, S. A.

Kvartærgeologiske Iagttagelser i Egnen syd for Sor $\varnothing$.

Meddr dansk geol. Foren., 6, 22, 1$30(\mathrm{G})$

Andersen, S. A.

1929

Nyere Iagttagelser over Afsmeltningens Forløb paa Sjælland.

Meddr dansk geol. Foren., 7, 353-356

Andersen, S. A.

Om Aase og Terrasser inden for Susaa's Vandomraade og deres Vidnesbyrd om Isafsmeltningens Forl $\varnothing$ b.

Danm. geol. Unders., II, 54, 201p (E)

Andersen, S. A.

The waning of the last continental glacier in Denmark as illustrated by varved clay and eskers.

J. Geol., 39, 609-624

Andersen, S. A.

1950

Rågeleje Egnens geologi.

Meddr dansk geol. Foren., 11, 543$557(\mathrm{E})$
Berthelsen, A.

1974

Nogle forekomster af intrusivt moræneler i NØ-Sjælland.

Dansk geol. Foren. Årsskrift 1973, 118$131(\mathrm{E})$

Hansen, $\mathrm{K}$.

The Geology and Bottom Deposits of Lake Tystrup Sø, Zealand.

Danm. geol. Unders., II, 76, 52p

Hansen, S.

Om Forekomster af Glacialflager af paleocæn Mergel paa Sjælland.

Danm. geol. Unders., IV, 2, 7, 22p (G)

Hansen, S. og A. V. Nielsen

Ekskursion til Syd-Sjælland, Vest-Møn,

Falster og Lolland.

(Ekskursionsberetning)

Meddr dansk geol. Foren., 14, 455-459

Hansen, S. og V. Nordmann 1950

Ekskursion til Slagelse-Korsør-egnen.

(Ekskursionsberetning)

Meddr dansk geol. Foren., 11, 603-607

Krüger, J. 1969

Landskabsformer i sydlige Sjælland.

Geogr. Tidsskr., 68, 105-212 (E)

Milthers, K.

Indlandsisens Moræner omkring København.

Naturens Verden, 21, 289-301

Milthers, V. 1908

Kortbladene Faxe og Stevns Klint.

Danm. geol. Unders., I, 11, 291p (F)

Milthers, V.

Grundlinier i Isens Bortsmeltning fra Sjælland.

Skand. Naturforskermøde. Kristiania 1916. Forh., 410-421

Milthers, V.

1923

Kalk og Mergel paa Sjælland.

Danm. geol. Unders., III, 23, 80p

Milthers, V.

1935

Nordøstsjællands Geologi.

Danm. geol. Unders., V, 3, 192p

Milthers, V.

Nordvestsjællands Geologi.

Danm. geol. Unders., V, 6, 185p 
Petersen, K. Strand og P. B. Konradi 1974 Lithologisk og palæontologisk beskrivelse af profiler i Kvartæret på Sjælland.

Dansk geol. Foren. Årsskrift 1973, 47$56(\mathrm{E})$

Rasmussen, L. Aabo 1974 Om morænestratigrafi i det nordlige Øresundsområde.

Dansk geol. Foren. Årsskrift 1973, 132 139 (E)

Rørdam, K.

1893

Kortbladene Helsing $\varnothing \mathrm{r}$ og Hiller $\varnothing$ d.

Danm. geol. Unders., I, 1, 110p (F)

Rørdam, K.

1899

Kortbladene Kjøbenhavn og Roskilde.

Danm. geol. Unders., I, 6, 108p (F)

Rørdam, K. og V. Milthers

Kortbladene Sejrø, Nykøbing, Kalundborg og Holbæk.

Danm. geol. Unders., I, 8, 143p (F)

Sjørring, S.

1973

Some problems in the till stratigraphy of the northeastern part of Sjaelland.

Bull. geol. Instn Univ. Upsala, 5, 31-35

Wennberg, G.

1949

Differentialrörelser i Inlandsisen.

Sista Istiden i Danmark, Skåne och Östersjön.

Meddn Lunds geol.-min. Instn, 114, 201p

$\emptyset$ dum, H.

Marint Interglacial paa Sjælland, Hven, Møn og Rügen.

Danm. geol. Unders., IV, 2, 10, 44p (G)

\section{Lolland-Falster}

Lolland-Falster

Andersen, S. A.

Lolland i sidste istid.

Meddr dansk geol. Foren., 13, 225$235(\mathrm{E})$

Haarsted, V.

De kvartærgeologiske og geomorfologiske forhold paa Møn.

Meddr dansk geol. Foren., 13, 124-126

Hammermüller, $B$.

1907
Entwicklung des Bodenreliefs, StrömtäIcr und Künstenbildung.

Inaug.-Diss. Leipzig., 133p

Hansen, S. og A. V. Nielsen

1961

Ekskursion til Syd-Sjælland, Vest-Møn,

Falster og Lolland.

(Ekskursionsberetning)

Meddr dansk geol. Foren., 14, 455-459

Nordmann, $\mathrm{V}$.

1927

Træk af Lollands Geologi.

Lolland-Falster historiske Samfund, Aarbog, 15, 1-15

\section{Bornholm}

Bornholm

Grönwall, K. A. og V. Milthers

1916 Kortbladet Bornholm.

Danm. geol. Unders., I, 13, 281p (F)

Gry, $\mathrm{H}$.

1960

Geology of Bornholm.

Int. Geol. Congr. 21. Guide to excursions nos. A45 and C40

Johnsson, G.

1951

Studier över hällskulpturen på Bornholm. Meddr dansk geol. Foren., 12, 67-82 (E)

Milthers, V.

Bornholms Geologi.

Danm. geol. Unders., V, 1, 140p

Munthe, $\mathrm{H}$.

Iakttagelser öfver qvartära aflagringar på Bornholm.

Geol. For. Stockh. Forh., 11, 274-287

Wennberg, G.

1949

Differentialrörelser i Inlandsisen.

Sista Istiden i Danmark, Skåne och Östersjön.

Meddn Lunds geol.-min. Instn., 114, $201 p$

Laaland-Falster. 
Stratigraphical descriptions

Stratigrafiske beskrivelser

Andersen, S, A.

1966

En fremstilling af Danmarks Kvartærgeologi.

(Diskussion. Se Hansen, S. 1965 og 1966)

Meddr dansk geol. Foren., 16, 214-229 og 232-233

Andersen, S. A.

1950

Rågeleje Egnens geologi.

Meddr dansk geol. Foren., 11, 543$557(\mathrm{E})$

Berthelsen, A.

1973

Weichselian ice advances and drift successions in Denmark.

Bull. geol. Instn Univ. Upsala, 5, 21-29

De Geer, G.

1884

Om den skandinaviska landisens andra utbredning.

Geol. For. Stockh. Forh., 7, 436-466

Gagel, C.

1913

Ueber das Alter der Moräne am Emmerleff-Kliff und die Beweiskraft der "Leitgeschiebe" fur das Alter der Moränen.

Zentbl. Miner., 7, 215-224

Hansen, S.

1965

The Quaternary of Denmark.

(Påfølgende diskussion se Andersen, S.

A. 1966 og Hansen, S. 1966)

Rankama, K. (ed.), The geologic systems, 1, New York. 1-90

Hansen, S.

1966

Bemærkninger til hr. S. A. Andersens kritiske anmeldelse af "The Quaternary of Denmark".

(Diskussion. Se Andersen, S. A. 1966 og Hansen, S. 1965)

Meddr dansk geol. Foren., 16, 230-232

Jessen, A.

1899

Kortbladene Skagen, Hirshals, Frederiks-

havn. Hjøring og Løkken.

Danm. geol. Unders., 1, 3, 368p (F)

Jessen, A.

Klinten ved Halkhoved.

Danm. geol. Unders., IV, 2, 8, 26p (E)
Jessen, A.

Kortbladet Haderslev.

Danm. geol. Unders., I, 17, 95p (F)

Jessen, A., V. Milthers,

V. Nordmann, N. Hartz og A. Hesselbo

En Boring gennem de kvartære Lag ved

Skærumhede.

Danm. geol. Undes., II, 25, 175p (E)

Jessen, K. og V. Milthers

1928

Stratigraphical and Paleontological Studies of Interglacial Fresch-water Deposits in Jutland and Nortwest Germany.

Danm. geol. Unders., II, 48, 379p

Madsen, E.

1968

En arkæologisk-geologisk undersøgelse af klinten ved Ejby Bro, Isefjord.

Meddr dansk geol. Foren., 18, 33-45 (E).

Madsen, $\mathrm{V}$.

Om inddelingen af de danske Kvartærdannelser.

Meddr dansk geol. Foren., 1, 5, 1-22

Madsen, V. og V. Nordmann 1940

Kvartæret i Røgle Klint ved Lillebelt.

Danm. geol. Unders., II, 58, 142p (F)

Madsen, V., V. Nordmann, 1900

K. I. V. Steenstrup og E. Østrup

Leda pernula Leret ved Selbjerggaard i Vester Hanherred.

Meddr dansk geol. Foren., 1, 6, 1-18

Madsen, V., V. Nordmann og

1908

N. Hartz

Eem-Zonerne.

Studier over Cyprinaleret og andre EemAflejringer i Danmark, Nord-Tyskland og Holland.

Danm. geol. Unders., II, 17, 302p (F)

Mertz, E. L.

Geologiske Profiler gennem danske Sunde og Fjorde; med nogle Bemærkninger om dertil knyttede geotekniske Forhold.

Danm. geol. Unders., II, 60, 143p (F)

Milthers, K.

Ledeblokke og Landskabsformer i Danmark.

(Påfølgende diskussion se Andersen, S.

A. 1945 og Milthers, K. 1945)

Danm. geol. Unders., II, 69, 137p (E) 
Tellina calcaria Leret ved Høve i Odsherred.

Meddr dansk geol. Foren., 1, 6, 37-44 Münnich, G.

Quantitative Geschiebeprofile aus Dänemark und Nordostdeutschland mit besonderer Berücksichtigung Vorpommerns.

Abh. geol.-paleont. Inst. Greifswald, 15, $1-52$

Nordmann, V.

1918

Om Inddelingen af Nordeuropas Kvartær paa Grundlag af Iagttagelser i Danmark. Skand. Naturforskermøde. Kristiania 1916. Forh., 414-419
Oversigt over Danmarks Geologi.

Danm. geol. Unders., V, 4, 208p

$(\mathrm{E} / \mathrm{F} / \mathrm{G})$

Penck, A.

Die Geschiebeformation Norddeutschlands.

Z. dt. geol. Ges., 31, 117-203

Ussing, N. V.

1903

Om et nyt Findested for marint Diluvium ved Hostrup i Salling.

Vidensk. Meddr dansk naturh. Foren., 111-123 


\section{Lodgement till and melt-out till Bundtill og udsmeltningstill}

Hansen, S.

1930

Om Forekomster af Glacialflager af paleocæn Mergel paa Sjælland.

Danm. geol. Unders., IV, 2, 7, 22p (G)

Jessen, A.

Kortbladene Skagen, Hirshals, Frederikshavn, Hjøring og Løkken.

Danm. geol. Unders., 1, 3, 368p (F)

Jessen, A.

1905

Kortbladene Aalborg og Nibe (nordlige

Del).

Danm. geol. Unders., I, 10, 193p (F)

Jessen, A.

Kortbladet Skamlingsbanke.

Danm. geol. Unders., I, 12, 99p (F)

Johnstrup, F. 1875

De geognostiske Forhold i Jylland.

Tidsskr. for Landøkonomi. København, $1-31$

Johnstrup, F.

1882

Oversigt over de geognostiske Forhold i

Danmark.

V. Falbe Hansen og W. Scharling (eds),

Danmarks Statistik, 1, 31-83 København

Milthers, K.

1959

Kortbladene Fåborg, Svendborg og Gulstav.

A: Kvartære aflejringer.

Danm. geol. Unders., I, 21A, 112p (E)

Milthers, V.

Kortbladene Faxe og Stevns Klint.

Danm. geol. Unders., I, 11, 299p (F)

Milthers, V.

Glacialgeologiske Retningslinjer i

Odense Egnen.

Danm. geol. Unders., IV, 2, 4, 24p
Milthers, V.

1935

Nordøstsjællands Geologi.

Danm. geol. Unders., V, 3, 192p

Milthers, V.

Nordvestsjællands Geologi.

Danm. geol. Unders., V, 6, 185p

Pingel, V.

1886

Dansk Geologi.

Tilskueren, 478-490 og 629-642

Rørdam, K. og V. Milthers

Kortbladene Sejrø, Nykøbing, Kalundborg og Holbæk.

Danm. geol. Unders., 1, 8, 143p (F)

Smed, P.

Studier over den fynske øgruppes glaciale landskabsformer.

(Påfølgende diskussion se Andersen, S. A. 1963 og Smed, P. 1963)

Meddr dansk geol. Foren., 15, 1-74 (E)

\section{Ablation till \\ Ablationstill}

Hansen, S.

1940

Varvigheden i danske og skaanske senglaciale Aflejringer.

Danm. geol. Unders., II, 63, 478p (E)

Jessen, A.

1899

Kortbladene Skagen, Hirshals, Frederikshavn, Hjøring og Løkken.

Danm. geol. Unders., 1, 3, 368p (F)

Jessen, A.

1905

Kortbladene Aalborg og Nibe (nordlige Del).

Danm. geol. Unders., I, 10, 193p (F) 
Jessen, A.

Kortbladet Skamlingsbanke.

Danm. geol. Unders., I, 12, 99p (F)

Marcussen, I.

1973

Studies on flow till in Denmark.

Boreas, 2, 213-231

Milthers, $\mathrm{V}$.

Nordøstsjællands Geologi.

Danm. geol. Unders., V, 3, 192p

Rasmussen, H. Wienberg

1965

Strukturer dannet ved jordflydning, udglidning og iss $\emptyset$-tapning i kvartære smeltevandsaflejringer.

Meddr dansk geol. Foren., 15, 470$485(\mathrm{E})$

Rasmussen, L. Aabo

1974

Om morænestratigrafi i det nordlige Øresundsområde.

Dansk geol. Foren. Årsskrift 1973, 132 $139(\mathrm{E})$

Rørdam, K. og V. Milthers

1900

Kortbladene Sejrø, Nykøbing, Kalundborg og Holbæk.

Danm. geol. Unders., I, 8, 143p (F)

Sjørring, S.

1974

Klinterne ved Hundested.

Danm. geol. Foren. Årsskrift 1973, 108$117(\mathrm{E})$

\section{Deformation till and glacio-tectonic deformation \\ Deformationstill og glacial tektonik}

Berthelsen, A.

1974

Nogle forekomster af intrusivt moræneler

i NØ-Sjælland.

Dansk geol. Foren. Årsskrift 1973, 118$131(\mathrm{E})$

Branth, J. S. Deichmann 1881

Geologiske Forhold i det nordlige Jylland.

Tidsskr. for populær Fremstilling af $\mathrm{Na}$ turvidenskaben, 275-281
Gripp, K.

1947

Jasmund und Möen, eine glacialmorphologische Untersuchung.

Erdkunde, 1, 175-182

Gry, $\mathrm{H}$.

1940

De istektoniske Forhold i Molerområdet.

Meddr dansk geol. Foren., 9, 586-627

Gry, $\mathrm{H}$.

1964

Furs Geologi

Dansk Natur - Dansk Skole,

Årsskrift 1964, 45-55

Gry, H., K. Hansen,

1941

V. Madsen og V. Nordmann

Diskussion om vore dislocerede Klinters

Dannelse.

Meddr dansk geol. Foren., 10, 39-51

Gry, H., E. Heller og I. Madirazza 1969

Ekskursion til NV-Jylland. 6.-8. august

1968. (Ekskursionsberetning)

Meddr dansk geol. Foren., 19, 119-123

Hansen, S.

1930

Om Forekomster af Glacialflager af paleocæn Mergel paa Sjælland.

Danm. geol. Unders., IV, 2, 7, 22p (G)

Hansen, S.

1966

Ekskursion til Sønderjylland, 5.-7. august 1965. (Ekskursionsberetning)

Meddr dansk geol. Foren., 16, 246-255

Hartz, N. og V. Milthers

1901

Det senglaciale Ler i Allerød Teglværksgrav.

Meddr dansk geol. Foren., 2, 8, 31-60

Jessen, A.

1916

Om Dislokationerne i Lønstrup Klint.

Danm. geol. Unders., IV, 1, 4, 28p (E)

Jessen, A.

Klinten ved Halkhoved.

Danm. geol. Unders., IV, 2, 8, 26p (E)

Jessen, A.

1931

Lønstrup Klint.

Danm. geol. Unders., II, 49, 142p (E)

Jessen, A.

Kortbladet Sønderborg.

Danm. geol. Unders., I, 20, 91p (F)

Johnstrup, F.

1882

Om de geologiske Forhold i den nordlige

Del af Vendsyssel. 
Indbydelsesskrift til Universitets Aarsfest, København, 1-43

Krüger, J. 1969

Landskabsformer i sydlige Sjælland

Geogr. Tidsskr., 68, 105-212 (E)

Madsen, $\mathrm{V}$.

Ristinge Klint.

Danm. geol. Unders., IV, 1, 2, 32p (F)

Madsen, V.

Kvartære Dislokationer.

Skand. Naturforskermøde. Kristiania 1916. Forh., 421-428

Madsen, V.

Røgle Klint, et naturligt Profil gennem en eocæn Horst og dens kvartære Forland.

Naturens Verden, 219-232

Madsen, V. og V. Nordmann

Kvartæret i Røgle Klint ved Lillebelt.

Danm. geol. Unders., II, 58, 142p (F)

Madsen, V., V. Nordmann og

1908

N. Hartz

Eem-Zonerne.

Studier over Cyprinaleret og andre Eem-

Aflejringer i Danmark, Nord-Tyskland og Holland.

Danm. geol. Unders., II, 17, 302p (F)

Madsen. V., V. Hintze, 1915

V. Nordmann og E. M. Nørregaard

Om Aarsagen til Dislokationerne i vore Klinter.

Meddr dansk geol. Foren., 4, 433-442

Milthers, V.

1935

Nordøstsjællands Geologi.

Danm. geol. Unders., V, 3, 192p

Nielsen, O. Bjørslev

1973

Eocæne aflejringer i Ølst-området og deres indpasning i områdets kvartærgeologi. Dansk geol. Foren. Årsskrift 1972, $100-110$

Nordmann, V. 1928

Ekskursion til Vejle-Fredericia egnen.

(Ekskursionsberetning)

Meddr dansk geol. Foren., 7 ,

239-246

Nordmann, V.

Den fredede Røgle Klint.

Danmark, 4, 600-606
Petersen, K. Strand

1973

Tills in dislocated drift deposits on the Røsnaes peninsula, nordwestern Sjaelland, Denmark.

Bull. geol. Instn Univ. Upsala, 5, 41-49

Petersen, K. Strand og A. Buch

1974

Dislocated tills with Paleogene and Pleistocene marine beds. Tectonics, Lithology, macro - and microfossils.

Danm. geol. Unders. Årbog 1973, 6391 (D)

Petersen, K. Strand og P. B. Konradi 1974 Lithologisk og palæontologisk beskrivelse af profiler i Kvartæret på Sjælland.

Dansk geol. Foren. Arsskrift 1973, 47$56(\mathrm{E})$

Rasmussen, H. Wienberg

Undersøgelser og tolkninger af dislocerede issøbakker.

Meddr dansk geol. Foren., 17, 37-57 (E)

Rasmussen, L. Aabo

Om morænestratigrafi i det nordlige Øresundsområde.

Dansk geol. Foren. Årsskrift 1973, 132 139 (E)

Ravn, J. P. J.

Om en Spalte i Kalkstenen ved Faxe.

Meddr dansk geol. Foren., 3, 513-526

Rosenkrantz, A.

1944

Nye Bidrag til Forstaaelsen af Ristinge Klints Opbygning.

Meddr dansk geol. Foren., 10, 431-435

Rørdam, K. og V. Milthers

1900

Kortbladene Sejrø, Nykøbing, Kalundborg og Holbæk.

Danm. geol. Unders., I, 8, 143p (F)

Sjørring, S.

Some problems in the till stratigraphy of the northeastern part of Sjaelland.

Bull. geol. Instn Univ. Upsala, 5, 31-35

Sjørring, S.

1974

Klinterne ved Hundested.

Dansk geol. Foren. Årsskrift 1973, 108$117(\mathrm{E})$

Slater, G.

1926

The structure of the disturbed deposits of Möens klint and Lönstrup, Denmark.

J. Sci. Trans. Oxford., 21-22 
The disturbed glacial Deposits in the Neighbourhood of Lønstrup, near Hjørring, North Denmark.

Trans. R. Soc. Edinb., 55, 303-315

Slater, G.

The structure of the disturbed deposits of Møens klint, Denmark.

Trans. R. Soc. Edinb., 55, 289-302

Thamdrup, K. 1970

Klinten ved Mols Hoved.

En kvartærgeologisk unders $\emptyset$ gelse. Dansk geol. Foren. Årsskrift 1969, 2$8(\mathrm{E})$
Om Floddale og Randmoræner i Jylland.

K. danske Vidensk. Selsk. Skr., 4, 160$213(\mathrm{~F})$

Wennberg, G.

1949

Differentialrörelser i Inlandsisen.

Sista Istiden i Danmark, Skåne och Östersjön.

Meddn Lunds geol.-min. Instn., 114, 201p

Ødum, $\mathrm{H}$.

1933

Marint Interglacial paa Sjælland, Hven, Møn og Rügen.

Danm. geol. Unders., IV , 2, 10, 44p (G) 


\section{Morphology \\ Morfologi}

\section{Ground moraine \\ Bundmoræne}

Andersen, S. A.

1957

Lolland i sidste istid.

Meddr dansk geol. Foren., 13, 225$235(\mathrm{E})$

Johnstrup, F. 1875

De geognostiske Forhold i Jylland.

Tidsskr. for Landøkonomi, København, 1-31

Johnstrup, F.

1882

Oversigt over de geognostiske Forhold i

Danmark.

V. Falbe Hansen og W. Scharling (eds), Danmarks Statistik. 1, 31-83, København

Krüger, J.

1969

Landskabsformer i sydlige Sjælland.

Geogr. Tidsskr., 68, 105-212 (E)

Milthers, K.

Indlandsisens Moræner omkring København.

Naturens Verden, 21, 289-301

Milthers, $\mathrm{K}$.

Erosionsformer i Midtjyllands Tertiæroverflade.

Meddr dansk geol. Foren., 10, 101-107

Milthers, $\mathrm{K}$.

Landskabsformerne i en Del af Nordsjælland.

Dansk Natur - Dansk Skole, 16-21

Milthers, $\mathrm{K}$

Kortbladene Fåborg, Svendborg og Gulstav.

A: Kvartære aflejringer.

Danm. geol. Unders., I, 21, A, 112p (E)

Milthers, V.

1908

Kortbladene Faxe og Stevns Klint.
Danm. geol. Unders., I, 11, 291p (F)

Milthers, V.

Nordøstsjællands Geologi.

Danm. geol. Unders., V, 3, 192p

Milthers, V.

Nordvestsjællands Geologi.

Danm. geol. Unders., V, 6, 185p

Milthers, $\mathrm{V}$.

Det danske Istidslandskabs Terrænformer og deres Opstaaen.

Danm. geol. Unders., III, 28, 233p (E)

Nordmann, V.

1958

Kortbladet Fredericia.

A: Kvartære aflejringer.

Danm. geol. Unders., I, 22A, 125p (E)

Petersen, F. Schausen

1958

Landskabet.

Huhle, R. (ed.), Bogen om Himmerland, Aabenraa. 7-43

Rørdam, K. og V. Milthers

1900

Kortbladene Sejrø, Nykøbing, Kalundborg og Holbæk.

Danm. geol. Unders., I, 8, 143p (F)

Smed, P.

1962

Studier over den fynske øgruppes glaciale landskabsformer.

(Påfølgende diskussion se Andersen, S.

A. 1963 og Smed, P. 1963)

Meddr dansk geol. Foren., 15, 1-74

\section{Ridges parallel to the ice movement}

Rygge parallel med isbevægelsen

Andersen, S. A.

1931

Om Aase og Terrasser inden for Susaa's Vandomraade og deres Vidnesbyrd om 
Isafsmeltningens Forløb.

Danm. geol. Unders., II, 54, 201p (E)

Grönwall, K. A. og V. Milthers

1916

Kortbladet Bornholm.

Danm. geol. Unders., I, 13, 281p (F)

Hansen, K.

1950

The Geology and Bottom Deposits of

Lake Tystrup Sø, Zealand.

Danm. geol. Unders., II, 76, 52p

Hansen, K. 1954

Træk af Susåens Historie.

Naturens Verden, 38, 44-54

Jessen, A.

1936

Vendsyssels Geologi.

Danm. geol. Unders., V, 2, 195p

Jessen, A.

1945

Kortbladet Sønderborg.

Danm. geol. Unders., I, 20, 91p (F)

Krüger, J.

1969

Landskabsformer i sydlige Sjælland.

Geogr. Tidsskr., 68, 105-212 (E)

Krüger, J.

1970

Till fabric in relation to direction of ice movement.

Geogr. Tidsskr., 69, 133-170 (D)

Milthers, K.

Kortbladene Fåborg, Svendborg og Gulstav.

A: Kvartære aflejringer.

Danm. geol. Unders., I, 21A, 112p (E)

Milthers, V.

Det danske Istidslandskabs Terrænformer og deres Opstaaen.

Danm. geol. Unders., III, 28, 233p (E)

Rørdam, K. og V. Milthers

1900

Kortbladene Sejrø, Nykøbing, Kalundborg og Holbæk.

Danm. geol. Unders., I, 8, 143p (F)

Smed, P.

1962

Studier over den fynske øgruppes glaciale landskabsformer.

(Påfølgende diskussion se Andersen, S.

A. 1963 og Smed, P. 1963)

Meddr dansk geol. Foren., 15, 1-74 (E)
Werth, E.

1907

Studien zur glazialen Bodengestaltung in den skandinavischen Ländern.

Z. Ges. Erdk. Berl., 27-43, 87-101

Ridges transverse to the ice movement

Rygge på tværs af isbevægelsen

Ahlmann, H. W.

1935

Kvartärgeologiska anteckningar till en exkursion genom Jylland.

Geol. For. Stockh. Forh., 57, 662-666

Andersen, H. Lykke

1968

Træk af Jelsh øj-buernes udviklingshistorie.

Meddr dansk geol. Foren., 18, 137-140

Andersen, S. A.

Grænsen for sidste Nedisning i Sønderjylland.

Meddr dansk geol. Foren., 6, Møder og ekskurs., 33-34

Andersen, S. A.

Kvartærgeologiske Iagttagelser i Egnen syd for Sor $\varnothing$.

Meddr dansk geol. Foren., 6, 22, 1$30(\mathrm{G})$

Andersen, S. A.

1927

Storebælt i nutid og fortid.

Geol. For. Stockh. Forh., 49, 427-437

Andersen, S. A.

Nyere Iagttagelser over Afsmeltningens Forløb paa Sjælland.

Meddr dansk geol. Foren., 7, 353-356

Andersen, S. A.

1931

Om Aase og Terrasser inden for Susaa's Vandomraade og deres Vidnesbyrd om Isafsmeltningens Forløb.

Danm. geol. Unders., II, 54, 201p (E)

Andersen, S. A.

$\emptyset$ stjylland, geologisk set.

$\emptyset$ stjydsk Hjemstavnsforen. Årsskrift, $72-80$

Andersen, S. A.

Den østjyske Israndslinie Nord for Aarhus.

Naturhistorisk Tidende, 4, 1-4 
Rågeleje Egnens geologi.

Meddr dansk geol. Foren., 11, 543$557(\mathrm{E})$

Andersen, S. A.

1965

Isens bortsmeltning $\mathrm{i}$ egnen mellem $\mathrm{Vi}$ borg og Grenå.

(Diskussion. Se Gripp, K. 1964 og 1965)

Meddr dansk geol. Foren., 15, 589-595, 596-597 (G)

Andersen, S. A.

1965

Om israndsliniekort $\mathrm{i}$ almindelighed - og

Per Smed's i særdeleshed.

(Diskussion. Se Smed, P. 1963)

Naturhistorisk Tidende, 1-2, 7-12

Andersen, S. A.

1967

Isens bortsmeltning i Limfjordsegnen.

(Diskussion. Se Gripp, K. 1966 og 1967)

Meddr dansk geol. Foren., 17, 138144 (G)

Andersen, S. A.

1968

Ekskursion fra Århus gennem terrænet vest for byen.

Meddr dansk geol. Foren., 18, 130-132

Eggers, W.

1927

Die Landschaftszonen Schleswig-Holsteins.

Die Heimat, 3, 6p

Eggers, W.

1930

Geomorphologische Übersichtskarte von

Schleswig.

Schleswig-Holsteinische Universitätgesellschaft, 25, 1

Gottsche, C.

1897

Endmoränen und das marine Diluvium Schleswig-Holstein's.

I. Die Endmoränen

Mitt. geogr. Ges. Hamburg, 13, 1-57

Gripp, K.

1954

Die Entstehung der Landschaft Ost

Schleswigs vom Dänischen Wohld bis Alsen.

Meyniana, 2, 81-123

Gripp, K.

1964

Der Verlauf der Eisrandlagen zwischen

Grenaa und Viborg.

(Påfølgende diskussion se Andersen, S.

A. 1965 og Gripp, K. 1965)

Meddr dansk geol. Foren., 15, 346-358

Gripp, K.

1965

Antwort an Herrn S. A. Andersen.

(Diskussion. Se Andersen, S. A. 1965 og

Gripp, K. 1964)

Meddr dansk geol. Foren., 15, 595-596

Gripp, K.

1966

Die Eisrandkerbe von Himmerland und der Abbau des würmzeitlichen Eises im Bereich des Limfjordes.

(Påfølgende diskusssion se Andersen, S.

A. 1967 og Gripp, K. 1967)

Meddr dansk geol. Foren., 16, 138-152

Gripp, K.

1967

Ueber den Wert von S. A. Andersen's Kritik.

(Diskussion. Se Andersen, S. A. 1967 og Gripp, K. 1966)

Meddr dansk geol. Foren., 17, 144145

Gripp, K.

Der Abbau des würmzeitlichen Eises im

Bereich des Kattegat.

Meddr dansk geol. Foren., 17, 58-75

Grönwall, K. A. og V. Milthers

1916

Kortbladet Bornholm.

Danm. geol. Unders., I, 13, 281p (F)

Haarsted, V.

1956

De kvartærgeologiske og geomorfologiske forhold paa Møn.

Meddr dansk geol. Foren., 13, 124-126

Hammermüller, B.

1907

Laaland-Falster.

Entwicklung des Bodenreliefs, Stromtäler und Künstbildung.

Inaug.-Diss. Leipzig., 133p

Hansen, $\mathrm{K}$.

The Geology and Bottom Deposits of Lake Tystrup Sø, Zealand.

Danm. geol. Unders., II, 76, 52p

Hansen, $\mathrm{K}$.

Landskabsudviklingen i Himmelbjergegnen.

Meddr dansk geol. Foren., 13, 542-545

Hansen, S.

1965

Kortbladet Tinglev.

Danm. geol. Unders., I, 23.

( 2 kort, teksten er ikke udgivet) 
Hansen, S.

Ekskursion til Sønderjylland,

5.-7. august 1965.(Ekskursionsberetning)

Meddr dansk geol. Foren., 16, 246-255

Hansen, S. og A. V. Nielsen

1961

Ekskursion til Syd-Sjælland, Vest-Møn,

Falster og Lolland.

(Ekskursionsberetning)

Meddr dansk geol. Foren., 14, 455-459

Hansen, S. og V. Nordmann

1950

Ekskursion til Slagelse-Korsør-egnen.

(Ekskursionsberetning)

Meddr dansk geol. Foren., 11, 603-607

Hansen, S., V. Nordmann og 1947

Th. Sorgenfrei

Ekskursion til Nordslesvig.

(Ekskursionsberetning)

Meddr dansk geol. Foren., 11, 229-236

Harder, P.

1908

En østjydsk Israndslinie.

Danm. geol. Unders., II, 19, 259p (E)

Hartz, N. og V. Milthers

Det senglaciale Ler i Allerød Teglværksgrav.

Meddr dansk geol. Foren., 2, 8, 31-60

Jessen, A.

1905

Kortbladene Aalborg og Nibe (nordlige Del).

Danm. geol. Unders., I, 10, 193p (F)

Jessen, A.

1922

Kortbladet Varde.

Danm. geol. Unders., I, 14, 105p

Jessen, A

1925

Kortbladet Blaavandshuk.

Danm. geol. Unders., I, 16, 76p (F)

Jessen, A.

Demonstration af Israndlinier i Sønderjylland.

Meddr dansk geol. Foren., 8, 546

Jessen, A.

1935

Kortbladet Haderslev.

Danm. geol. Unders., I, 17, 95p (F)

Jessen, A.

Vendsyssels Geologi.

Danm. geol. Unders., V, 2, 195p

Jessen, A.

1945

Kortbladet Sønderborg.

Danm. geol. Unders., I, 20, 91p (F)
Johnstrup, F.

1875

De geognostiske Forhold i Jylland.

Tidsskr. for Landøkonomi, København, $1-31$

Krüger, J. 1969

Landskabsformer i sydlige Sjælland.

Geogr. Tidsskr., 68, 105-212 (E)

Madsen, V.

1903

Om den glaciale, isdæmmede Sø ved Stenstrup paa Fyn samt om Dannelsen af Teglværksleret i Stenstrup-Egnen.

Danm. geol. Unders., II, 14, 86p (F)

Madsen, V.

1921

Terrainformerne paa Skovbjerg Bakkeø.

Danm. geol. Unders., IV , 1, 12, 24p (F)

Madsen, $\mathrm{V}$.

1931

Ledeblokke og Israndsstadier i det centrale Danmark.

(Diskussion. Se Milthers, V. 1931 og 1931)

Meddr dansk geol. Foren., 8, 140-141

Milthers, K.

1935

Landskabets Udformning mellem Alheden og Limfjorden.

Danm. geol. Unders., III, 56, 36p (G)

Milthers, $\mathrm{K}$.

Indlandsisens Moræner omkring København.

Naturens Verden, 21, 289-301

Milthers, $\mathrm{K}$.

1942

Ledeblokke og Landskabsformer i Danmark.

(Påfølgende diskussion se Andersen, S.

A. og Milthers, K. 1945)

Danm. geol. Unders., II, 69, 137p (E)

Milthers, K.

1955

Landskabsformerne i en Del af Nordsjælland.

Dansk Natur - Dansk Skole, 16-21

Milthers, $\mathrm{K}$.

1959

Kortbladene Fåborg, Svendborg og Gulstav.

A: Kvartære aflejringer.

Danm. geol. Unders., I, 21A, 112p (E)

Milthers, V.

1906

Er Næstved-Mogenstrup Aasen en Endemoræne?

Meddr dansk geol. Foren., 2, 12, 89-90 
Milthers, V.

Kortbladene Faxe og Stevns Klint.

Danm. geol. Unders., I, 11, 291p (F)

Milthers, V.

1918

Grundlinier i Isens Bortsmeltning fra

Sjælland.

Skand. Naturforskermøde. Kristiania 1916. Forh., 410-421

Milthers, V.

1925

Kortbladet Bakke.

Danm. geol. Unders., I, 15, 175p (F)

Milthers, V.

On the so-called gothi-glacial limit in Denmark.

Geogr. Annlr., 3, 162-172

Milthers, V. 1928

Glacialgeologiske Retningslinjer i

Odense Egnen.

Danm. geol. Unders., IV, 2, 4, 24p

Milthers, $\mathrm{V}$.

1929

Lidt om Landskabet omkring Brænde Aa paa Fyn.

Geogr. Tidsskr., 32, 217-221

Milthers, V.

1930

Bornholms Geologi.

Danm. geol. Unders., V, 1, 140p

Milthers, V.

Israndens Tilbagerykning fra Østjylland til Sjælland-Fyn, belyst ved Ledeblokke.

(Påfølgende diskussion se Madsen, V.

1931 og Milthers, V. 1931)

Meddr dansk geol. Foren., 8, 1-70

Samme udgivet 1932 i Danm. geol. Unders., IV, 2, 9, 70p (G)

Milthers, V.

Ledeblokke og Israndsstadier i det centrale Danmark.

(Diskussion. Se Madsen, V. 1931 og Milthers, V. 1931)

Meddr dansk geol. Foren., 8, 139-142

Milthers, V.

Nordøstsjællands Geologi.

Danm. geol. Unders., V, 3, 192p

Milthers, V.

Kortbladet Brande.

Danm. geol. Unders., I, 18, 162p (F)

Milthers, $\mathrm{V}$.

Kortbladet Vissenbjærg.

Danm. geol. Unders., I, 19, 143p (F)
Milthers, V.

1948

Det danske Istidslandskabs Terrænformer og deres Opstaaen.

Danm. geol. Unders., III, 28, 233p (E)

Milthers, V. og Th. Claudi West

Viborg Egnens Mergellag, deres geologiske Omgivelser og deres Udnyttelse.

Danm. geol. Unders., III, 9, 70p

Møller, J. M.

1928

Træk af Aarhusegnens Geologi.

Jydsk Foren. for Naturvidenskab i Aarhus, 21-40

Møller, M.

Fra Aarhus-Dalen til Horsens Fjord.

Meddr dansk geol. Foren., 7, 151-164

Nordmann, V.

Israndslinier paa Kortbladet "Fredericia".

Meddr dansk geol. Foren., 7, 171-175

Nordmann, V.

1928

Ekskursion til Vejle-Fredericia egnen.

(Ekskursionsberetning)

Meddr dansk geol. Foren., 7, 239-246

Nordmann, $V$.

1943

Himmerlands Tilblivelse.

Turistforeningen for Danmark. Aarbog, 9-23

Nordmann, $\mathrm{V}$.

1958

Kortbladet Fredericia.

A: Kvartære aflejringer.

Danm. geol. Unders., I, 22A, 125p (E)

Nordmann, V. (ed)

1928

Oversigt over Danmarks Geologi.

Danm. geol. Unders., V, 4, 208p(E/F/G)

Petersen, F. Schausen

1958

Landskabet.

I: Huhle, R. (ed.), Bogen om Himmerland, Aabenraa. 7-43

Rørdam, K. og V. Milthers

1900

Kortbladene Sejrø, Nykøbing, Kalundborg og Holbæk.

Danm. geol. Unders., I, 8, 143p (F)

Simonsen, K.

1927

Sorøegnens Geologi.

Aarbog for Historisk Samfund for Sorø Amt, 15, 22-35 
Sjørring, S.

1973

Some problems in the till stratigraphy of the northeastern part of Sjaelland.

Bull. geol. Instn Univ. Upsala, 5, 31-35

Smed, P.

1962

Studier over den fynske $\emptyset$ gruppes glaciale landskabsformer.

(Påfølgende diskussion se Andersen, S.

A. 1963 og Smed, P. 1963)

Meddr dansk geol. Foren., 15, 1-74 (E)

Smed, P.

1963

Israndsliniekort.

(Påfølgende diskussion se Andersen, S. A. 1965)

Biologi og Geografi, 4, 66-67

Steensby, H. P.

1925

Om de danske Öers geografiske Udvikling i senglacial tid.

Geogr. Annlr., 23-80

Ussing, N. V.

1903

Om Jyllands Hedesletter og Teorierne for deres Dannelse.

K. danske Vidensk. Selsk. Skr., 2, 99$165(\mathrm{~F})$

Ussing, N. V.

Om Floddale og Randmoræner i Jylland.

K. danske Vidensk. Selsk. Skr., 4, 160$213(\mathrm{~F})$

Werth, E.

1907

Studien zur glazialen Bodengestaltung in den skandinavischen Ländern.

Z. Ges. Erdk. Berl., 27-43, 87-101

Woldstedt, P.

1913

Beiträge zur Morphologie von Nordschleswig.

Mitt. geogr. Ges. naturh. Mus. Lübeck, $2,26,1-70$

Woldstedt, P.

1926

Probleme der Seenbildung in Norddeutschland.

Zeit. Gesell. Erdkunde, Berlin, 103-124

$\emptyset$ dum, $\mathbf{H}$.

1927

Bemærkninger om Vestgrænsen for den sidste Nedisning i Nordslesvig.

Meddr dansk geol. Foren., 7, 170-171 $\varnothing$ dum, $\mathrm{H}$.

Kvartæret omkring Hobro.

Danm. geol. Unders., IV, 4, 10, 23p (G)

\section{Formations of ablation}

\section{Afsætninger af ablationsmoræne}

Andersen, S. A.

1931

The waning of the last continental glacier in Denmark as illustrated by varved clay and eskers.

J. Geol., 39, 609-624

Hansen, K.

1950

The Geology and Bottom Deposits of

Lake Tystrup Sø, Zealand.

Danm. geol. Unders., II, 76, 52p

Hansen, K.

1954

Træk af Susåens Historie.

Naturens Verden, 38, 44-54

Jessen, A.

1935

Kortbladet Haderslev.

Danm. geol. Unders., I, 17, 95p

Jessen, A.

1936

Vendsyssels Geologi.

Danm. geol. Unders., V, 2, 195p

Jessen, A.

1945

Kortbladet Sønderborg.

Danm. geol. Unders., I, 20, 91p (F)

Krüger, J.

1969

Landskabsformer i sydlige Sjælland.

Geogr. Tidsskr., 68, 105-212 (E)

Madsen, V.

1902

Kortbladet Nyborg.

Danm. geol. Unders., I, 9, 182p (F)

Milthers, K.

1955

Landskabsformerne i en Del af Nordsjælland.

Dansk Natur - Dansk Skole, 16-21

Milthers, V.

Lidt om Landskabet omkring Brænde Aa paa Fyn.

Geogr. Tidsskr., 32, 217-221

Milthers, V.

1935

Nordøstsjællands Geologi.

Danm. geol. Unders., V, 3, 192p 
Milthers, V.

1939 Rasmussen, H. Wienberg

Kortbladet Brande.

Undersøgelser og tolkninger af disloce-

Danm. geol. Unders., I, 18, 162p (F) rede issøbakker.

Milthers, V.

Det danske Istidslandskabs Terrænformer og deres Opstaaen.

Meddr dansk geol. Foren., 17, 37-57 (E)

Danm. geol. Unders., III, 28, 233p (E)

$\emptyset$ dum, $\mathrm{H}$.

1969

Kvartæret omkring Hobro.

Danm. geol. Unders., IV, 4, 10, 23p (G)

Nordmann, V.

1958

Kortbladet Fredericia.

A: Kvartære aflejringer.

Danm. geol. Unders., I, 22A, 125p (E) 


\section{Till composition \\ Tillsammensætning}

Texture

Textur

\section{Grain size composition}

Kornstørrelses sammensatning

Andersen, H. Lykke 1973 En begravet dal i Præ-Kvartæret ved Århus.

Dansk geol. Foren. Årsskrift 1972, 111118

Bahnson, $\mathrm{H}$. 1973

Lithological investigations in some Danish boulder-clay profiles.

Bull. geol. Instn Univ. Upsala, 5, 93-109

Binzer, $\mathrm{K}$.

1974

Sedimentological and geochemical features of Weichselian tills and pre-Quaternary sediments in Denmark.

Danm. geol. Unders. Årbog 1973, 111131

Jessen, A.

1897

Kortbladene Læsø og Anholt.

Danm. geol. Unders., 1, 4, 48p (F)

Jessen, A.

Kortbladene Skagen, Hirshals, Frederikshavn, Hjøring og Løkken.

Danm. geol. Unders., 1, 3, 368p (F)

Jessen, A.

Kortbladene Aalborg og Nibe (nordlige

Del).

Danm. geol. Unders., I, 10, 193p (F)

Jessen, A

Kortbladet Skamlingsbanke.

Danm. geol. Unders., I, 12, 99p (F)

Jessen, A.

Lønstrup Klint.

Danm. geol. Unders., II, 49, 142p (E)
Jessen, A.

Kortbladet Haderslev.

Danm. geol. Unders., I, 17, 95p (F)

Johnstrup, F.

1875

De geognostiske Forhold i Jylland.

Tidsskr. for Landøkonomi, København, $1-31$

Madsen, V.

1900

Kortbladet Bogense.

Danm. geol. Unders., I, 7, 112p (F)

Marcussen, I.

Studies on flow till in Denmark.

Boreas, 2, 213-231

Mertz, E. L.

Geologiske Profiler gennem danske Sunde og Fjorde; med nogle Bemærkninger om dertil knyttede geotekniske Forhold.

Danm. geol. Unders., II, 60, 143p (F)

Mertz, E. L.

Vekselvirkningen mellem Geologi og Geoteknik.

Danm. geol. Unders., III, 29, 49p (E)

Milthers, V. 1908

Kortbladene Faxe og Stevns Klint.

Danm. geol. Unders., I, 11, 291p (F)

Milthers, V.

Jordbundsforholdene omkring Overlund ved Viborg.

Danm. geol. Unders., III, 19, 20p

Petersen, K. Strand 1973 Tills in dislocated drift deposits on the Røsnaes peninsula, northwestern Sjaelland, Denmark.

Bull. geol. Instn Univ. Upsala, 5, 41-49

Petersen, K. Strand og A. Buch

1974

Dislocated tills with Paleogene and Pleistocene marine beds. Tectonics, Litho- 
logy, macro - and microfossils.

Danm. geol. Unders. Årbog 1973, 6391 (D)

Petersen, K. Strand og P. B. Konradi 1974

Lithologisk og palæontologisk beskrivelse af profiler i Kvartæret på Sjælland.

Danm. geol. Unders. Årsskrift 1973, 47$56(\mathrm{E})$

Rørdam, K. 1893

Kortbladene Helsingør og Hillerød.

Danm. geol. Unders., I, 1, 110p (F)

Rørdam, K. 1894

Geologisk-agronomiske Undersøgelser ved Lyngby Landboskole og Brede Ladegaard.

Danm. geol. Unders., II, 3, 49p

Fabric, grain shape and roundness

Fabric, korn form og afrundethed

Andersen, S. A.

1957

Lolland i sidste istid.

Meddr dansk geol. Foren., 13, 225235 (E)

Andersen, S. A.

1967

Isens bortsmeltning i Limfjordsegnen.

(Diskussion. Se Gripp, K. 1966 og 1967)

Meddr dansk geol. Foren., 17, 138144 (G)

Gripp, K.

Ueber den Wert von S. A. Andersen's Kritik.

(Diskussion. Se Andersen, S. A. 1967 og Gripp, K. 1966)

Meddr dansk geol. Foren., 17, 144-145

Hansen, S.

1942

En isskuret "Brolægning" på Egnen NØ for Odense.

Meddr dansk geol. Foren., 10, 119-129

Helland, A.

1879

Ueber die glacialen Bildungen der nordeuropäischen Ebene.

Z. dt. geol. Ges., 31, 63-106

Krüger, J.

1969

Landskabsformer i sydlige Sjælland.

Geogr. Tidsskr., 68, 105-212 (E)
Krüger, J.

Till fabric in relation to direction of ice movement.

Geogr. Tidsskr., 69, 133-170 (D)

Liboriussen, $\mathbf{J}$.

1972

Fabric-studier af smeltevandsgrus og moræneler $\mathrm{i}$ den nordlige del af kortbladet Randers.

Dansk geol. Foren. Årsskrift 1971, 31-35

Nielsen, A. V.

1961

Lind $\emptyset$, et af Keld Milthers sidste kvartærgeologiske arbejdsfelter.

Meddr dansk geol. Foren., 14, 453- 454

Nørregaard, E. M.

1912

Bovbjerg - Profilet.

Meddr dansk geol. Foren., 4, 47-54

Rasmussen, L. Aabo

1974

Om morænestratigrafi i det nordlige Øresundsområde.

Dansk geol. Foren. Årsskrift 1973, 132139 (E)

\section{Structure}

\section{Strukturer}

Andersen, S. A.

1965

Isens bortsmeltning $\mathrm{i}$ egnen mellem $\mathrm{Vi}$ borg og Grenå.

(Diskussion. Se Gripp, K. 1964 og 1965)

Meddr dansk geol. Foren., 15, 589-595, 596-597 (G)

Branth, J. S. Deichmann

1881

Geologiske Forhold i det nordlige Jylland.

Tidsskr. for populær Fremstilling af Naturvidenskaben, 275-281

Bøggild, O. B.

Om Skurestriber i Danmark og beslægtede Fænomener.

Meddr dansk geol. Foren., 1, 5, 73-104

Gripp, K. 1965

Antwort an Herrn S. A. Andersen.

(Diskussion. Se Andersen, S. A. 1965 og Gripp, K. 1964)

Meddr dansk geol. Foren., 15, 595-596 
Grönwall, K. A. og V. Milthers

1916

Kortbladet Bornholm.

Danm. geol. Unders., I, 13, 281p (F)

Gry, $\mathrm{H}$.

1960

Geology of Bornholm.

Int. Geol. Congr. 21.

Guide to excursions nos. A45 and C40

Johnsson, G.

1951

Studier över hällskulpturen pả Bornholm. Meddr dansk geol. Foren., 12, 67-82 (E)

Johnstrup, F.

1882

Nogle Iagttagelser over Glacialphænomenerne og Cyprina-Leret i Danmark.

Indbydelsesskrift til Universitets Fest, København, 1-74

Krüger, J.

1969

Landskabsformer i sydlige Sjælland.

Geogr. Tidsskr., 68, 105-212 (E)

Krüger, J.

1970

Till fabric in relation to direction of ice movement.

Geogr. Tidsskr., 69, 133-170 (D)

Marcussen, I.

1973

Studies on flow till in Denmark.

Boreas, 2, 213-231

Milthers, V.

1901

Skurstriberne ved Fakse.

Meddr dansk geol. Foren., 2, 8, 1-20

Milthers, V. 1908

Kortbladene Faxe og Stevns Klint.

Danm. geol. Unders., I, 11, 291p (F)

Milthers, V.

Bornholms Geologi.

Danm. geol. Unders., V, 1, 140p

Rørdam, K. og V. Milthers

1900

Kortbladene Sejr $\varnothing$, Nykøbing, Kalundborg og Holbæk.

Danm. geol. Unders., I, 8, 143p (F)

Sarauw, G. F. L.

1904

En Belægning af isskurede Blokke i $\mathrm{Ny}$ mølle Grusgrav ved Hedehusene.

Meddr dansk geol. Foren., 2, 143-144

Ussing, N. V. og V. Madsen

1897

Kortbladet Hindsholm.

Danm. geol. Unders., I, 2, 87p (F)
Lithological composition

Litologisk sammensætning

Andersen, S. A.

1932

Blokstudier og Isstrømme.

(Diskussion. Se Gry, H. 1932)

Meddr dansk geol. Foren., 8, 201-204

Andersen, S. A.

1945

Isstrømmenes Retning over Danmark i den sidste Istid, belyst ved Ledeblokunders $\emptyset$ gelser.

(Diskussion. Se Milthers, K. 1942 og 1945)

Meddr dansk geol. Foren., 10, 594 608 og 612-614

Andersen, S. A.

1950

Rågeleje Egnens geologi.

Meddr dansk geol. Foren., 11, 543$557(\mathrm{E})$

Gottsche, C.

1883

Sedimentaer-Geschiebe der Provinz Schleswig-Holstein.

Yokohama, 66p

Gry, $\mathbf{H}$.

1932

Blokstudier og Isstrømme.

(Diskussion. Se Andersen, S. A. 1932)

Meddr dansk geol. Foren., 8, 204-206

Milthers, K.

1945

Om Ledeblokkenes Spredning.

(Diskussion. Se Andersen, S. A. 1945 og Milthers, K. 1942)

Meddr dansk geol. Foren., 10, 609-612 og 614-615

Milthers, V.

1925

Danmarks Jord.

K. Hansen (ed.): Det danske Landbrugs Historie, København, 74p

Ussing, N. V.

1903

Om et nyt Findested for marint Diluvium ved Hostrup i Salling.

Vidensk. Meddr. dansk naturh. Foren., 111-123 
Fine material $(<2 \mathrm{~mm})$

Fint materiale $(<2 \mathrm{~mm})$

Graff-Petersen, P. 1957

The Clay-Minerals in some Danish Quaternary Sediments.

Geol. For. Stock. Forh., 79, 773-774

Graff-Petersen, P. 1958

Lermineralogiske unders $\emptyset$ gelser af Kvartærbjergarterne i Røjle Klint.

Meddr dansk geol. Foren., 13, 471$501(\mathrm{E})$

Petersen, K. Strand og P. B. Konradi 1974 Lithologisk og palæontologisk beskrivelse af profiler i Kvartæret på Sjælland.

Dansk geol. Foren. Årsskrift 1973, 47-56

Coarse material ( $>2 \mathrm{~mm}$ )

Groft materiale (>2 $\mathrm{mm}$ )

Bahnson, $\mathrm{H}$.

1973

Lithological investigations in some Danish boulder-clay profiles.

Bull. geol. Instn Univ. Upsala, 5, 93-109

De Geer, G. 1885

Ueber die zweite Ausbreitung des Skandinavischen Landeseises.

Z. dt. geol. Ges., 37, 177-213

Gottsche, C. 1886

Diluviale Verbreitung tertiärer $\mathrm{Ge}$ schiebe.

Z. dt. geol. Ges., 36B, 247-250

Grönwall, K. A.

1904

Om løse Blokkes Betydning for Kendskabet til Danmarks Geologi.

Meddr dansk geol. Foren., 2, 10, 1-12

Grönwall, K. A.

1904

Forsteningsførende Blokke fra Langeland, Sydfyn og Ærø samt Bemærkninger om de ældre Teriærdannelser i det baltiske Omraade.

Danm. geol. Unders., II, 15, 62p (F)

Grönwall, K. A. og V. Milthers

1916

Kortbladet Bornholm.

Danm. geol. Unders., I, 13, 281p (F)
Hammermüller, B.

1907

Laaland-Falster. Entwicklung des Bodenreliefs, Stromtäler und Künstenbildung.

Inaug.-Diss. Leipzig, 133p

Helland, A.

1879

Ueber die glacialen Bildungen der nordeuropäischen Ebene.

Z. dt. geol. Ges., 31, 63-106

Jessen, A.

1905

Kortbladene Aalborg og Nibe (nordlige Del).

Danm. geol. Unders., I, 10, 193p (F)

Jessen, A.

Kortbladet Skamlingsbanke.

Danm. geol. Unders., I, 12, 99p (F)

Jessen, A.

Lønstrup Klint.

Danm. geol. Unders., II, 49, 142p (E)

Jessen, A.

Kortbladet Haderslev.

Danm. geol. Unders., I, 17, 95p (F)

Jessen, A.

1936

Vendsyssels Geologi.

Danm. geol. Unders., V, 2, 195p

Jessen, A., V. Milthers,

V. Nordmann, N. Hartz og A. Hesselbo

En Boring gennem de kvartære Lag ved

Skærumhede.

Danm. geol. Undes., II, 25, 175p (E)

Milthers, V.

1905

Woher stammen die sogenannten

"Rödö"-Quarzporphyrgeschiebe im baltischen Diluvium?

Meddr.dansk geol. Foren. , 2, 11, 113-118

Sarauw, G. F. L.

1912

Vore store Sten (Vandreblokke), deres

Registrering og Fredning.

Meddr dansk geol. Foren., 4, 111-112

Wolf, W.

1913

Geologisch-agronomische Karte der Umgegend von Apenrade nebst Erläuterungen.

K. geol. Landesanstalt. Berlin, 22p

$\varnothing$ dum, $H$.

1968

Flintkonglomeratet i Jylland.

Meddr dansk geol. Foren., 18, 1-32 
$\emptyset$ dum, $\mathbf{H}$.

Kvartæret omkring Hobro.

Danm. geol. Unders., IV, 4, 10, 23p (G)

Stone countings

Stentællinger

Bahnson, $\mathrm{H}$. 1973

Lithological investigations in some Danish boulder-clay profiles.

Bull. geol. Instn Univ. Upsala, 5, 93- 109

Binzer, $\mathrm{K}$.

1974

Sedimentological and geochemical features of Weichselian tills and pre-Quaternary sediments in Denmark.

Danm. geol. Unders. Årbog 1973, 111131

Jessen, A.

1897

Kortbladene Læs $\emptyset$ og Anholt.

Danm. geol. Unders., 1, 4, 48p (F)

Jessen, A.

Kortbladene Skagen, Hirshals, Frederikshavn, Hjøring og Løkken.

Danm. geol. Unders., 1, 3, 368p (F)

Jessen, A.

Kortbladet Skamlingsbanke.

Danm. geol. Unders., I, 12, 99p (F)

Jessen, A.

Kortbladet Varde.

Danm. geol. Unders., I, 14, 105p (F)

Jessen, A.

Klinten ved Halkhoved.

Danm. geol. Unders., IV, 2, 8, 26p (E)

Jessen, A.

1936

Vendsyssels Geologi.

Danm. geol. Unders., V, 2, 195p

Krüger, J.

1969

Landskabsformer i sydlige Sjælland.

Geogr. Tidsskr., 68, 105-212 (E)

Madsen, V.

1897

Kortbladet Sams $\varnothing$.

Danm. geol. Unders., I, 5, 87p

Madsen, V.

1900

Kortbladet Bogense.

Danm. geol. Unders., I, 7, 112p (F)
Madsen, V.

Kortbladet Nyborg.

Danm. geol. Unders., I, 9, 182p (F)

Madsen, V.

1916

Ristinge Klint.

Danm. geol. Unders., IV, 1, 2, 32p (F)

Madsen, V. og V. Nordmann

Kvartæret i Røgle Klint ved Lillebelt.

Danm. geol. Unders., II, 58, 142p (F)

Madsen, V., V. Nordmann

1908

og N. Hartz

Eem-Zonerne.

Studier over Cyprinaleret og andre EemAflejringer i Danmark, Nord-Tyskland og Holland.

Danm. geol. Unders., II, 17, 302p (F)

Marcussen, I.

Stones in Danish tills as a stratigraphical tool - a review.

Bull. geol. Instn Univ. Upsala, 5, 177-181

Marcussen, I.

1974

Stentællingsmetoden, ledeblokanalysen og glacialstratigrafi - En kritisk vurdering. Dansk geol. Foren. Årsskrift 1973, 20 42 (E)

Milthers, $\mathrm{V}$.

1925

Kortbladet Bække.

Danm. geol. Unders., I, 15, 175p (F)

Milthers, V.

Kortbladet Brande.

Danm. geol. Unders., I, 18, 162p (F)

Münnich, G.

1936

Quantitative Geschiebeprofile aus Dänemark und Nordostdeutschland mit besonderer Berücksichtigung Vorpommerns.

Abh. geol.-paleont. Inst. Greifswald, 15, $1-52$

Nordmann, V.

1928

La position stratigraphique des Dépôts d'Eem.

Danm. geol. Unders., II, 47, 81p (D)

Nørregaard, E. M.

1912

Bovbjerg - Profilet.

Meddr dansk geol. Foren., 4, 47-54

Petersen, K. Strand

1973

Tills in dislocated drift deposits on the Røsnaes peninsula, northwestern Sjaelland, Denmark. 
Bull. geol. Instn Univ. Upsala, 5, 41-49

Petersen, K. Strand og A. Buch

1974

Dislocated tills with Paleogene and Pleistocene marine beds. Tectonics, Lithology, macro - and microfossils.

Danm. geol. Unders. Årbog 1973, 6391 (D)

Petersen, K. Strand og P. B. Konradi 1974 Lithologisk og palæontologisk beskrivelse af profiler i Kvartæret på Sjælland.

Dansk geol. Foren. Årsskrift 1973, 47$56(\mathrm{E})$

Rørdam, K.

1893

Kortbladene Helsing ør og Hillerød.

Danm. geol. Unders., I, 1, 110p (F)

Rørdam, K. og V. Milthers

1900

Kortbladene Sejrø, Nykøbing, Kalundborg og Holbæk.

Danm. geol. Unders., I, 8, 143p (F)

Sjørring, S.

1973

Some problems in the till stratigraphy of the northeastern part of Sjaelland.

Bull. geol. Instn Univ. Upsala, 5, 31-35

Ussing, N. V. og V. Madsen

1897

Kortbladet Hindsholm.

Danm. geol. Unders., I, 2, 87p (F)

Indicator boulder analysis

Ledebloks analyser

Berthelsen, A.

Nogle ledebloktællinger på Horsensegnen.

Meddr dansk geol. Foren., 11, 449455 (E)

Branth, J. S. Deichmann

1876

Hvorfra og hvorledes ere Stenene i det nordlige Jylland komne?

Tidsskr. for populær Fremstilling af Naturvidenskaben, 5. R., 3, 161-180.

De Geer, G.

1884

Om den skandinaviska landisens andra utbredning.

Geol. For. Stock. Forh., 7, 436-466

Grönwall, K. A. og V. Milthers 1916

Kortbladet Bornholm.

Danm. geol. Unders., I, 13, 281p (F)
Gry, $\mathrm{H}$.

1974

Ledeblokkes kornstørrelsesforhold og transportmåde.

Dansk geol. Foren. Årsskrift 1973, 140 $151(\mathrm{E})$

Hesemann, J. 1931

Das Glazialdiluviums Dänemarks, Hollands und Norddeutschlands vom geschiebekundlichen Standpunkt aus.

Geol. Rundschau, 22, 145-160

Jessen, A.

Kortbladene Læs $\varnothing$ og Anholt.

Danm. geol. Unders., 1, 4, 48p (F)

Jessen, A.

1922

Kortbladet Varde.

Danm. geol. Unders., I, 14, 105p (F)

Jessen, A.

Kortbladet Blaavandshuk.

Danm. geol. Unders., I, 16, 76p (F)

Johnstrup, F. 1875

De geognostiske Forhold i Jylland.

Tidsskr. for Landøkonomi, København, 1-31

Johnstrup, F.

1882

Nogle Iagttagelser over Glacialphænomenerne og Cyprina-Leret i Danmark.

Indbydelsesskrift til Universitets Fest, København, 1-74

Johnstrup, F. 1882

Om de geologiske Forhold i den nordlige Del af Vendsyssel.

Indbydelsesskrift til Universitets Aarfest, København, 1-43

Knattrup, N.

1955

Markens og strandens sten.

Natur og Museum, Århus, 4, 2, 1-14

Krüger, J.

1969

Landskabsformer i sydlige Sjælland.

Geogr. Tidsskr., 68, 105-212 (E)

Krüger, J. 1974

Traditionelle ledeblokkes egnethed til brug i kvantitative analyser.

Dansk geol. Foren. Årsskrift 1973, 152161

Madsen, $\mathrm{V}$ 1897

Kortbladet Sams $\emptyset$.

Danm. geol. Unders., I, 5, 87p 
Madsen, $\mathrm{V}$.

1899

Om inddelingen af de danske Kvartærdannelser.

Meddr dansk geol. Foren., 1, 5, 1-22

Marcussen, I.

1973

Stones in Danish tills as a stratigraphical tool - a review.

Bull. geol. Instn Univ. Upsala, 5, 177-181

Marcussen, I.

1974

Stentællingsmetoden, ledeblokanalysen og glacialstratigrafi - En kritisk vurdering.

Dansk geol. Foren. Årsskrift 1973, 20$42(\mathrm{E})$

Milthers, $\mathrm{K}$.

1941

Stenene og det danske Landskab.

Dansk Natur-Dansk Skole,

København., 59p

Samme udgivet i 1963 i København

Milthers, K.

1942

Ledeblokke og Landskabsformer i Danmark.

(Påfølgende diskussion se Andersen, S.

A. 1945 og Milthers, K. 1945)

Danm. geol. Unders., II, 69, 137p (E)

Milthers, K.

Nogle Betragtninger over Isens Tilførselsveje til Danmark.

Geol. For. Stock. Forh., 68, 479-481

Milthers, V.

1899

Norske Blokke paa Sjælland.

Meddr dansk geol. Foren., 1, 5, 49-64

Milthers, V.

1908

Kortbladene Faxe og Stevns Klint.

Danm. geol. Unders., I, 11, 291p (F)

Milthers, V.

1909

Scandinavian Indicator-Boulders in the Quaternary deposits.

Danm. geol. Unders., II, 23, 153p (D)

Milthers, V.

Ledeblokke i de skandinaviske Nedisningers sydvestlige Grænseegne.

Meddr dansk geol.Foren., 4, 115-.182 (G)

Milthers, V.

1925

Kortbladet Bække.

Danm. geol. Unders., I, 15, 175p (F)

Milthers, V.

Betydningsfulde Forekomster af Basaltblokke i Jylland.

Meddr dansk geol. Foren., 7, 309-316
Milthers, V.

1930

Bornholms Geologi.

Danm. geol. Unders., V, 1, 140p

Milthers, V.

1931

Israndens Tilbagerykning fra $\emptyset$ stjylland til Sjælland-Fyn, belyst ved Ledeblokke. (Påfølgende diskussion se Madsen, V. 1931 og Milthers, V. 1931)

Meddr dansk geol. Foren., 8, 1-70

Samme udgivet 1932 i Danm. geol. Unders., IV, 2, 9, 70p (G)

Milthers, V.

1934

Die Verteilung skandinavischer Leitgeschiebe im Quartär von Westdeutschland. Abh. preuss. geol. Landesanst. N. F., 156, 1-74

Milthers, V.

1935

Nordøstsjællands Geologi.

Danm. geol. Unders., V, 3, 192p

Milthers, V.

1936

Geschiebeuntersuchungen und Glazialstratigraphie.

Z. dt. geol. Ges., 88, 115-120

Milthers, V.

Beiträge skandinavischer Leitgeschiebe für die Bestimmung der Vereisungsgrenzen.

Z. dt. geol. Ges., 91, 261-272

Milthers, V.

1939

Kortbladet Brande.

Danm. geol. Unders., I, 18, 162p (F)

Milthers, V. 1940

Kortbladet Vissenbjærg.

Danm. geol. Unders., I, 19, 143p (F)

Milthers, V.

Nordvestsjællands Geologi.

Danm. geol. Unders., V, 6, 185p

Milthers, V.

1948

Et Tilbageblik over Strejftog efter Ledeblokke gennem 40 Aar 1989-1937.

Meddr dansk geol. Foren., 11, 247305 (E)

Milthers, V. 1948

Fund af Basaltblokke i Sydjylland og Sønderjylland.

Meddr dansk geol. Foren., 11, 267-268

Milthers, V.

1955

Et vestjysk istidsområde.

Meddr dansk geol. Foren., 13, 61-78 
Milthers, V.

1957

Sydvestjyllands glaciale lagforhold.

Meddr dansk geol. Foren., 13, 206$216(\mathrm{E})$

Milthers, V.

1960

Stenenes vandringer i Istiden.

Naturens Verden, 338-346

Munthe, $\mathrm{H}$.

1889

Iakttagelser öfver qvartära aflagringar på Bornholm.

Geol. For. Stockh. Forh., 11, 274-287

Rørdam, K. 1893

Kortbladene Helsingør og Hillerød.

Danm. geol. Unders., I, 1, 110p (F)

Rørdam, K. og C. Bartholin

1897

Om Forekomsten af Juraforsteninger i løse Blokke i Moræneler ved København.

Danm. geol. Unders., II, 7, 16p

Rørdam, K. og V. Milthers 1900

Kortbladene Sejrø, Nykøbing, Kalundborg og Holbæk.

Danm. geol. Unders., I, 8, 143p (F)

Sjørring, S.

Klinterne ved Hundested.

Dansk geol. Foren. Årsskrift 1973, 108117 (E)

Ussing, N. V. og V. Madsen

1897

Kortbladet Hindsholm.

Danm. geol. Unders., I, 2, 87p (F)

Wennberg, G.

1949

Differentialrörelser i Inlandsisen.

Sista Istiden i Danmark, Skåne och Österjön.

Meddn Lunds geol.-min. Instn., 114, $201 p$

Wennberg, G.

Über den Geschiebetransport im Inlandeis.

Schr. naturw. Ver. Schlesw.-Holst., 25, 108-114

\section{Geochemistry \\ Geokemi}

Bahnson, $\mathrm{H}$.

1973

Lithological investigations in some Danish boulder-clay profiles.

Bull. geol. Instn Univ. Upsala, 5, 93-109

Binzer, $\mathrm{K}$.

Trace elements in Danish tills.

Bull. geol. Instn Univ. Upsala, 5, 111-115

Binzer, $\mathrm{K}$.

1974

Sedimentological and geochemical features of Weichselian tills and pre-Quaternary sediments in Denmark.

Danm. geol. Unders. Årbog 1973, 111131

Hammermüller, B.

1907

Laaland-Falster.

Entwicklung des Bodenreliefs, Stromtäler und Künstenbildung.

Inaug.-Diss, Leipzig, 133p

Jessen, A.

1905

Kortbladene Aalborg og Nibe (nordlige Del).

Danm. geol. Unders., I, 10, 193p (F)

Jessen, A.

Kortbladet Skamlingsbanke.

Danm. geol. Unders., I, 12, 99p (F)

Jessen, A.

1922

Kortbladet Varde.

Danm. geol. Unders., I, 14, 105p (F)

Jessen, A.

Kortbladet Blaavandshuk.

Danm. geol. Unders., I, 16, 76p (F)

Jessen, A.

Kortbladet Haderslev.

Danm. geol. Unders., I, 17, 95p (F)

Jessen, A.

Vendsyssels Geologi.

Danm. geol. Unders., V, 2, 195p

Jessen, A.

Kortbladet Sønderborg.

Danm. geol. Unders., I, 20, 91p (F)

Jessen, A., V. Milthers, V. Nordmann, N.

Hartz og A. Hesselbo

1910

En Boring gennem de kvartære Lag ved

Skærumhede.

Danm. geol. Unders., II, 25, 175p 
Madsen, V.

Kortbladet Bogense.

Danm. geol. Unders., I, 7, 112p (F)

Madsen, $\mathrm{V}$.

Kortbladet Nyborg.

Danm. geol. Unders., I, 9, 182p (F)

Madsen, $\mathrm{V}$.

Om den glaciale, isdæmmede $\mathrm{S} \varnothing$ ved Stenstrup paa Fyn samt om Dannelsen af Teglværksleret i Stenstrup-Egnen.

Danm. geol. Unders., II, 14, 86p (F)

Madsen, V.

Terrainformerne paa Skovbjerg Bakkeø.

Danm. geol. Unders., IV, 1, 12, 24p (F)

Madsen, V., V. Nordmann og

1908

N. Hartz

Eem-Zonerne.

Studier over Cyprinaleret og andre EemAflejringer i Danmark, Nord-Tyskland og Holland.

Danm. geol. Unders., II, 17, 302p (F)

Mertz, E. L.

Geologiske Profiler gennem danske Sunde og Fjorde; med nogle Bemærkninger om dertil knyttede geotekniske Forhold.

Danm. geol. Unders., II, 60, 143p (F)

Milthers, K.

Kortbladene Fåborg, Svendborg og Gulstav.

A: Kvartære aflejringer.

Danm. geol. Unders., I, 21A, 112p (E)

Milthers, V.

1908

Kortbladene Faxe og Stevns Klint.

Danm. geol. Unders., I, 11, 291p (F)

Milthers, V.

1914

Mergel og Kalk i det nordvestlige

Jylland.

Danm. geol. Unders., III, 11, 24p

Milthers, V.

Mergelaflejringerne i Hammerum Herred.

Danm. geol. Unders., III, 13, 21p

Milthers, V.

Mergelen i Holstebro Egnen.

Danm. geol. Unders., III, 15, 18p

Milthers, $\mathrm{V}$.

Mergelen i Djursland.

Danm. geol. Unders., III, 18, 41p

1917
Milthers, V.

1920

Jordbundsforholdene omkring Overlund ved Viborg.

Danm. geol. Unders., III, 19, 20p

Milthers, V.

Kalk og Mergel paa Sjælland.

Danm. geol. Unders., III, 23, 80p

Milthers, V.

1925

Kortbladet Bække.

Danm. geol. Unders., I, 15, 175p (F)

Milthers, V.

Kortbladet Brande.

Danm. geol. Unders., I, 18, 162p (F)

Milthers, V.

Kortbladet Vissenbjærg.

Danm. geol. Unders., I, 19, 143p (F)

Milthers, V. og Th. Claudi Westh 1913

Viborg Egnens Mergellag, deres geologiske Omgivelser og deres Udnyttelse.

Danm. geol. Unders., III, 9, 70p

Nordmann, $\mathrm{V}$.

1958

Kortbladet Fredericia.

A: Kvartære aflejringer.

Danm. geol. Unders., I, 22A, 125p (E)

Rørdam, K.

1894

Geologisk-agronomiske Undersøgelser ved Lyngby Landboskole og Brede Ladegaard.

Danm. geol. Unders., II, 3, 49p

Rørdam, K.

1899

Kortbladene Kjøbenhavn og Roskilde.

Danm. geol. Unders., I, 6, 108p (F)

\section{Fossils}

Fossiler

Andersen, S. Th.

1965

Pollen analysis and till stratigraphy at Lindø, Denmark.

Spec. Pap. geol. Soc. Am., 84, 65-78 (F/G)

Jessen, A.

1899

Kortbladene Skagen, Hirshals, Frederikshavn, Hjøring og Løkken.

Danm. geol. Unders., 1, 3, 368p (F) 
Jessen, A.

1905

Kortbladene Aalborg og Nibe (nordlige Del).

Danm. geol. Unders., I, 10, 193p (F) Jessen, A.

Kortbladet Haderslev.

Danm. geol. Unders., I, 17, 95p (F)

Jessen, A.

Vendsyssels Geologi.

Danm. geol. Unders., V, 2, 195p

Jessen, A.

1945

Kortbladet Sønderborg.

Danm. geol. Unders., I, 20, 91p (F)

Konradi, P. B.

1973

Foramineferas in some Danish glacial deposits.

Bull. geol. Instn Univ. Upsala, 5, 173-175

Madsen, V.

1895

Istidens Foraminiferer i Danmark og Holsten.

Meddr dansk geol. Foren., 1, 2, 1-229

Madsen, $V$.

1900

Kortbladet Bogense.

Danm. geol. Unders., I, 7, 112p (F)
Milthers, V.

1907

Vendsyssels aldre Yoldialer og den glaciale Lagfølge i Jylland.

Meddr dansk geol. Foren., 3, 1-12

Petersen, K. Strand og A. Buch 1974

Dislocated tills with Paleogene and Pleistocene marine beds. Tectonics, Lithology, macro- and microfossils.

Danm. geol. Unders. Årbog 1973, 6391 (D)

Petersen, K. Strand og P. B. Konradi 1974 Lithologisk og palæontologisk beskrivelse af profiler i Kvartæret på Sjælland.

Dansk geol. Foren. Årsskrift 1973, 47$56(\mathrm{E})$

Rørdam, K.

1893

Kortbladene Helsing $ø$ r og Hillerød.

Danm. geol. Unders., I, 1, 110p (F)

Rørdam, K. og V. Milthers

1900

Kortbladene Sejrø, Nykøbing, Kalundborg og Holbæk.

Danm. geol. Unders., I, 8, 143p (F) 


\section{Geotechnical and geophysical properties \\ Geotekniske og geofysiske forhold}

Bahnson, H. 1973 Lithological investigations in some Danish boulder-clay profiles.

Bull. geol. Instn Univ. Upsala, 5, 93-109 Jacobsen, $M$.

The undrained shear strength of preconsolidated boulder clay.

Proc. Eur. Congr. Soil Mech., Oslo. 1, 119-122

Jacobsen, M.

1970

Strength and deformation properties of preconsolidated moraine clay.

Geoteknisk Institut, Copenhagen. Bull. $27,21-45$

Mertz, E. L.

1926

Metoder til Unders $\emptyset$ gelse af Lerets fysiske Egenskaber.

Danm. geol. Unders., II, 44, 67p (E)
Mertz, E. L. 1937

Geologiske Profiler gennem danske Sunde og Fjorde; med nogle Bemærkninger om dertil knyttede geotekniske Forhold.

Danm. geol. Unders., II, 60, 143p (F)

Mertz, E. L.

Vekselvirkningen mellem Geologi og Geoteknik.

Danm. geol. Unders., HI, 29, 49p (E)

Rørdam, K. 1893

Kortbladene Helsingør og Hillerød.

Danm. geol. Unders., I, 1, 110p (F) 



\section{The authors index \\ Forfatterregister}

Ahlmann, H. W.

Kvartärgeologiska anteckningar till en exkursion genom Jylland.

Geol. For. Stockh. Forh., 57, 662-666.

3.3 .

Andersen, H. Lykke

1968

Træk af Jelshøj-buernes udviklingshisto-

rie.

Meddr dansk geol. Foren., 18, 137-140.

1.1.2., 3.3.

Andersen, H. Lykke

1973

En begravet dal i Præ-Kvartæret ved Århus.

Dansk geol. Foren. Årsskrift 1972, 111118.

1.1.2., 4.1.1.

Andersen, S. A.

1924

Grænsen for sidste Nedisning i Sønderjylland.

Meddr dansk geol. Foren., 6, Møder og ekskurs., 33-34.

3.3 .

Andersen, S. A.

1924

Kvartærgeologiske Iagttagelser i Egnen syd for Sorø.

Meddr dansk geol. Foren., 6, 22, 1-30

(G).

1.1.5., 3.3.

Andersen, S. A.

1927

Storebælt i nutid og fortid.

Geol. For. Stockh. Forh., 49, 427-437.

3.3.

Andersen, S. A.

1929

Nyere Iagttagelser over Afsmeltningens

Forløb paa Sjælland.

Meddr dansk geol. Foren., 7, 353-356.

1.1.5., 3.3.

Andersen, S. A.

Om Aase og Terrasser inden for Susaa's Vandomraade og deres Vidnesbyrd om
Isafsmeltningens Forløb.

Danm. geol. Unders., II, 54, 201p (E).

1.1.5., 3.2., 3.3.

Andersen, S. A.

1931

The waning of the last continental glacier in Denmark as illustrated by varved clay and eskers.

J. Geol., 39, 609-624.

1.1.5., 3.4.

Andersen, S. A.

1932

Blokstudier og Isstrømme.

(Diskussion. Se Gry, H. 1932)

Meddr dansk geol. Foren., 8, 201-204.

4.3 .

Andersen, S. A.

1933

Det danske Landskabs Historie.

København, 275p

1.1 .

Andersen, S. A. 1940

Den østjyske Israndslinie Nord for Aarhus.

Naturhistorisk Tidende, 4, 1-4.

3.3.

Andersen, S. A.

1940

$\emptyset$ stjylland, geologisk set.

Østjydsk Hjemstavnsforen. Årsskrift, 7280.

3.3 .

Andersen, S. A.

1945

Isstrømmenes Retning over Danmark i den sidste Istid, belyst ved Ledeblokundersøgelser.

(Diskussion. Se Milthers, K. 1942 og 1945)

Meddr dansk geol. Foren., 10, 594-608 og 612-614.

4.3 .

Andersen, S. A.

1946

Hvorledes Landet blev til.

Brunsgaard, C. og H. E. Pedersen (eds.), 
Landet mod nordvest-Thy og Vester Han Herred, København.

Bd.1, 7-32.

1.1.1.

Andersen, S. A.

1950

Rågeleje Egnens geologi.

Meddr dansk geol. Foren., 11, 543-557

(E).

1.1.5., 1.2., 3.3., 4.3.

Andersen, S. A.

1957

Lolland i sidste istid.

Meddr dansk geol. Foren., 13, 225-235 (E).

1.1.6., 3.1., 4.1.2.

Andersen, S. A.

1961

Geologisk fører over Vendsyssel.

København, 207p

1.1 .1

Andersen, S. A.

1963

Om Fyens glaciale terrænformer og deres opståen.

(Diskussion. Se Smed, P. 1962 og 1963)

Meddr dansk geol. Foren., 15, 223-228. 1.1.4.

Andersen, S. A.

1965

Isens bortsmeltning $\mathrm{i}$ egnen mellem $\mathrm{Vi}$ borg og Grenå.

(Diskussion. Se Gripp, K. 1964 og 1965)

Meddr dansk geol. Foren., 15, 589-595, 596-597 (G).

1.1.2., 3.3., 4.2.

Andersen, S. A.

$\mathrm{Om}$ israndsliniekort $\mathrm{i}$ almindelighed - og

Per Smed's i særdeleshed.

(Diskussion. Se Smed, P. 1963)

Naturhistorisk Tidende, 1-2, 7-12. 3.3.

Andersen, S. A.

1966

En fremstilling af Danmarks Kvartærgeologi.

(Diskussion. Se Hansen, S. 1965 og 1966)

Meddr dansk geol. Foren., 16, 214-229 og 232-233.

1.1., 1.2.

Andersen, S. A.

1967

Isens bortsmeltning i Limfjordsegnen.

(Diskussion. Se Gripp, K. 1966 og 1967)
Meddr dansk geol. Foren., 17, 138-144

(G).

1.1.1., 3.3., 4.1.2.

Andersen, S. A.

1968

Ekskursion fra Århus gennem terrænet vest for byen.

Meddr dansk geol. Foren., 18, 130-132.

1.1.2., 3.3.

Andersen, S. Th.

1965

Pollen analysis and till stratigraphy at Lindø, Denmark.

Spec. Pap. geol. Soc. Am., 84, 65-78 $(\mathrm{F} / \mathrm{G})$

4.5 .

Bahnson, $\mathrm{H}$.

1973

Lithological investigations in some Danish boulder-clay profiles.

Bull. geol. Instn Univ. Upsala, 5, 93-109. 4.1.1., 4.3.2., 4.3.2.1., 4.4., 5.

Bartholin, C.

1897

se Rørdam, K. og C. Bartholin

Berthelsen, A.

Nogle ledebloktallinger på Horsensegnen.

Meddr dansk geol. Foren., 11, 449-455

(E).

1.1.2., 4.3.2.2.

Berthelsen, A.

1973

Weichselian ice advances and drift successions in Denmark.

Bull. geol. Instn Univ. Upsala, 5, 21-29. 1.2 .

Berthelsen, A.

1974

Nogle forekomster af intrusivt moræneler i NØ-Sjælland.

Dansk geol. Foren. Årsskrift 1973, 118131 (E).

1.1.5., 2.3.

Binzer, $\mathrm{K}$.

1973

Trace elements in Danish tills.

Bull. geol. Instn Univ. Upsala, 5, 111115.

4.4 .

Binzer, $\mathbf{K}$.

1974

Sedimentological and geochemical features of Weichselian tills and pre-Quaternary sediments in Denmark. 
Danm. geol. Unders. Årbog 1973, 111131.

4.1.1., 4.3.2.1., 4.4.

Bornebusch, C. H. og. K. Milthers 1935 Jordbundskort over Danmark.

Danm geol. Unders., III, 24 (E). 1.1.

Branth, J. S. Deichmann 1876 Hvorfra og hvorledes ere Stenene i det nordlige Jylland komne?

Tidsskr. for populær Fremstilling af $\mathrm{Na}$ turvidenskaben, 5. R., 3, 161-180. 4.3.2.2.

Branth, J. S. Deichmann 1881 Geologiske Forhold i det nordlige Jylland.

Tidsskr. for populær Fremstilling af Naturvidenskaben, 275-281.

\section{3., 4.2.}

Buch, A.

se Petersen, K. Strand og A. Buch

Bøggild, O. B.

Om Skurestriber i Danmark og beslægtede Fænomener.

Meddr dansk geol. Foren., 1, 5, 73-104. 4.2 .

De Geer, G.

1884

Om den skandinaviska landisens andra utbredning.

Geol. For. Stock. Forh., 7, 436-466.

1.2., 4.3.2.2.

De Geer, G. 1885

Ueber die zweite Ausbreitung des Skandinavischen Landeseises.

Z. dt. geol. Ges., 37, 177-213.

4.3.2.

Eggers, W.

Die Landschaftszonen Schleswig-Holsteins.

Die Heimat, 3, 6p

3.3 .

Eggers, W.

1930

Geomorphologische Übersichtskarte von Schleswig.

Schleswig-Holsteinische Universitätgesellschaft, 25, 1

1.1.3., 3.3.
Gagel, C.

1913

Ucber das Alter der Moräne am Emmerleff-Kliff und die Beweiskraft der "Leitgeschiebe" fur das Alter der Moränen.

Zentbl. Miner., 7, 215-224.

1.2 .

Gottsche, C. 1883

Sedimentaer-Geschiebe der Provinz Schleswig-Holstein.

Yokohama, 66p

4.3 .

Gottsche, C.

1886

Diluviale Verbreitung tertiarer Geschiebe.

Z. dt. geol. Ges., 36B, 247-250.

4.3.2.

Gottsche, C.

Endmoränen und das marine Diluvium Schleswig-Holstein's.

I. Die Endmoranen

Mitt. geogr. Ges. Hamburg, 13, 1-57.

3.3 .

Graff-Petersen, P.

1957

The Clay-Minerals in some Danish Quaternary Sediments.

Geol. For. Stock. Forh., 79, 773-774.

4.3.1.

Graff-Petersen, P.

1958

Lermineralogiske undersøgelser af Kvartærbjergarterne i Røjle Klint.

Meddr dansk geol. Foren., 13, 471-501

(E).

4.3.1.

Gripp, K.

Jasmund und Möen, eine glacialmorpho-

logische Untersuchung.

Erdkunde, 1, 175-182.

2.3.

Gripp, K.

1954

Die Entstehung der Landschaft Ost Schleswigs vom Dänischen Wohld bis Alsen.

Meyniana, 2, 81-123.

3.3.

Gripp, K.

1964

Der Verlauf der Eisrandlagen zwischen

Grenaa und Viborg.

(Påfølgende diskussion se Andersen, S.

A. 1965 og Gripp, K. 1965) 
Meddr dansk geol. Foren., 15, 346-358. 1.1.2., 3.3.

Gripp, K.

1965

Antwort an Herrn S. A. Andersen.

(Diskussion. Se Andersen, S. A. 1965 og Gripp, K. 1964)

Meddr dansk geol. Foren., 15, 595-596.

1.1.2., 3.3., 4.2.

Gripp, K.

1966

Die Eisrandkerbe von Himmerland und der Abbau des würmzeitlichen Eises im Bereich des Limfjordes.

(Påfølgende diskusssion se Andersen, S.

A. 1967 og Gripp, K. 1967)

Meddr dansk geol. Foren., 16, 138-152.

1.1.1., 1.1.2., 3.3.

Gripp, K.

Der Abbau des würmzeitlichen Eises im

Bereich des Kattegat.

Meddr dansk geol. Foren., 17, 58-75 (E).

1.1., 3.3.

Gripp, K.

Ueber den Wert von S. A. Andersen's

Kritik.

(Diskussion. Se Andersen, S. A. 1967 og Gripp, K. 1966)

Meddr dansk geol. Foren., 17, 144-145

1.1.1., 3.3. , 4.1.2.

Grönwall, K. A.

1904

Forsteningsførende Blokke fra Langeland, Sydfyn og Ærø samt Bemærkninger om de ældre Tertiærdannelser i det baltiske Område.

Danm. geol. Unders., II, 15, 62p (F).

1.1.4., 4.3.2.

Grönwall, K. A.

1904

Om løse Blokkes Betydning for Kend-

skabet til Danmarks Geologi.

Meddr dansk geol. Foren., 2, 10, 1-12.

4.3.2.

Grönwall, K. A. og V. Milthers

1916

Kortbladet Bornholm.

Danm. geol. Unders., I, 13, 281p (F).

1.1.7., 3.2., 3.3., 4.2., 4.3.2., 4.3.2.2.

Gry, $\mathrm{H}$.

Blokstudier og Isstrømme.

(Diskussion. Se Andersen, S. A. 1932)

Meddr dansk geol. Foren., 8, 204-206.

4.3 .
Gry, $\mathrm{H}$.

1940

De istektoniske Forhold i Molerområdet.

Meddr dansk geol. Foren., 9, 586-627.

1.1.1., 2.3.

Gry, H., K. Hansen,

1941

V. Madsen og V. Nordmann

Diskussion om vore dislocerede Klinters

Dannelse.

Meddr dansk geol. Foren., 10, 39-51.

2.3 .

Gry, $\mathrm{H}$.

1960

Geology of Bornholm. Int. Geol. Congr.

21. Guide to excursions nos. A45 and C40.

1.1.7., 4.2.

Gry, $\mathbf{H}$.

1964

Furs Geologi

Dansk Natur - Dansk Skole, Årsskrift 1964, 45-55.

2.3.

Gry, H., E. Heller og I. Madirazza 1969

Ekskursion til NV-Jylland. 6.-8. august 1968.

(Ekskursionsberetning)

Meddr dansk geol. Foren., 19, 119-123. 2.3.

Gry, $\mathrm{H}$.

1974

Ledeblokkes kornstørrelsesforhold og transportmåde.

Dansk geol. Foren. Årsskrift 1973, 140$151(\mathrm{E})$.

4.3.2.2.

Haarsted, V.

1956

De kvartærgeologiske og geomorfologi-

ske forhold paa Møn.

Meddr dansk geol. Foren., 13, 124-126.

1.1.6., 3.3.

Haas, $\mathrm{H}$.

1889

Die geologische Bodenbeschaffenheit Schleswig-Holsteins.

Kiel und Leipzig, 152p

1.1.3.

Hammermüller, B.

1907

Laaland-Falster. Entwicklung des Bodenreliefs, Stromtäler und Künstenbildung. Inaug.-Diss, Leipzig, 133p 1.1.6., 3.3., 4.3.2., 4.4. 
Hansen, K.

1941

se Gry, H., K. Hansen, V. Madsen og V. Nordmann

Hansen, K.

1950

The Geology and Bottom Deposits of Lake Tystrup Sø, Zealand.

Danm. geol. Unders., II, 76, 52p

1.1.5., 3.2., 3.3., 3.4 .

Hansen, K.

1954

Træk af Susåens Historie.

Naturens Verden, 38, 44-54.

3.2., 3.4.

Hansen, K.

1958

Landskabsudviklingen i Himmelbjergegnen.

Meddr dansk geol. Foren., 13, 542-545.

1.1.2., 3.3.

Hansen, S.

1930

Om Forekomster af Glacialflager af paleocæn Mergel paa Sjælland.

Danm. geol. Unders., IV, 2, 7, 22p (G).

1.1.5., 2.1., 2.3.

Hansen, S.

1940

Varvigheden i danske og skaanske senglaciale Aflejringer.

Danm. geol. Unders., II, 63, 478p (E). 2.2 .

Hansen, S.

1942

En isskuret "Brolægning" på Egnen NØ for Odense.

Meddr dansk geol. Foren., 10, 119-129. 4.1.2.

Hansen, S., V. Nordmann og

1947

Th. Sorgenfrei

Ekskursion til Nordslesvig.

(Ekskursionsberetning)

Meddr dansk geol. Foren., 11, 229-236.

1.1.3., 3.3.

Hansen, S. og V. Nordmann

1950

Ekskursion til Slagelse-Korsør-egnen. (Ekskursionsberetning)

Meddr dansk geol. Foren., 11, 603-607. 1.1.5., 3.3.

Hansen, S. og A. V. Nielsen

1961

Ekskursion til Syd-Sjælland, Vest-Møn,

Falster og Lolland.

(Ekskursionsberetning)

Meddr dansk geol. Foren., 14, 455-459.

1.1.5., 1.1.6., 3.3.
Hansen, S.

1965

Kortbladet Tinglev.

Danm. geol. Unders., I, 23. (2 kort, teksten er ikke udgivet).

1.1.3., 3.3.

Hansen, S.

1965

The Quaternary of Denmark.

(Påfølgende diskussion se Andersen, S.

A. 1966 og Hansen, S. 1966)

Rankama, K. (ed.), The geologic systems, 1, New York. 1-90.

1.1., 1.2 .

Hansen, S.

1966

Bemærkninger til hr. S. A. Andersens kritiske anmeldelse af "The Quaternary of Denmark".

(Diskussion. Se Andersen, S. A. 1966 og

Hansen, S. 1965)

Meddr dansk geol. Foren., 16, 230-232.

1.1., 1.2.

Hansen, $\mathrm{S}$.

1966

Ekskursion til Sønderjylland, 5.-7. august 1965.

(Ekskursionsberetning)

Meddr dansk geol. Foren., 16, 246-255. 2.3., 3.3 .

Hansen, V.

1943

Østjylland - en geografisk Provins.

Geogr. Tidsskr., 46, 72-90.

1.1.2., 1.1.3.

Harder, P.

1908

En østjydsk Israndslinie.

Danm. geol. Unders., II, 19, 259p (E).

1.1.2., 3.3.

Hartz, N. og V. Milthers

1901

Det senglaciale Ler i Allerød Teglværksgrav.

Meddr dansk geol. Foren., 2, 8, 31-60.

2.3., 3.3.

Hartz, N.

1908

se Madsen, V., V. Nordmann og

N. Hartz

Hartz, N.

1910

se Jessen, A., V. Milthers, V. Nordmann,

N. Hartz og A. Hesselbo

Heck, H-L.

1949

se Wolf, W. og H-L. Heck 
Helland, A.

1879

Ueber die glacialen Bildungen der nordeuropäischen Ebene.

Z. dt. geol. Ges., 31, 63-106.

4.1.2., 4.3.2.

Heller, E. 1969

se Gry, H., E. Heller og I. Madirazza

Hesemann, J.

Das Glazialdiluviums Dänemarks, Hollands und Norddeutschlands vom geschiebekundlichen Standpunkt aus.

Geol. Rundschau, 22, 145-160.

4.3.2.2.

Hesselbo, A.

1910

se Jessen, A., V. Milthers, V. Nordmann, N. Hartz og A. Hesselbo

Hintze, $V$.

1915

se Madsen, V., V. Hintze, V. Nordmann og E. M. Nørregaard

Jacobsen, $\mathrm{M}$.

1967

The undrained shear strength of preconsolidated boulder clay.

Proc. Eur. Congr. Soil Mech., Oslo. 1, 119-122.

5.

Jacobsen, M.

1970

Strength and deformation properties of preconsolidated moraine clay.

Geoteknisk Institut, Copenhagen. Bull. $27,21-45$.

5.

Jessen, A.

1897

Kortbladene Læsø og Anholt.

Danm. geol. Unders., 1, 4, 48p (F).

1.1., 1.1.2., 4.1.1., 4.3.2.1., 4.3.2.2.

Jessen, A. 1899

Kortbladene Skagen, Hirshals, Frederikshavn, Hjøring og Løkken.

Danm. geol. Unders., 1, 3, 368p (F).

1.1.1., 1.2., 2.1., 2.2., 4.1.1., 4.3.2.1., 4.5 .

Jessen, A.

1905

Kortbladene Aalborg og Nibe (nordlige Del).

Danm. geol. Unders., I, 10, 193p (F).

1.1.1., 2.1., 2.2., 3.3., 4.1.1., 4.3.2., 4.4., 4.5 .

Jessen, A.

1907

Kortbladet Skamlingsbanke.
Danm. geol. Unders., I, 12, 99p (F).

1.1.3., 2.1., 2.2., 4.1.1., 4.3.2., 4.3.2.1., 4.4 .

Jessen, A., V. Milthers, 1910

V. Nordmann, N. Hartz og A. Hesselbo En Boring gennem de kvartære Lag ved Skærumhede.

Danm. geol. Unders., II, 25, 175p

1.2., 4.3.2., 4.4.

Jessen, A.

1916

Om Dislokationerne i Lønstrup Klint.

Danm. geol. Unders., IV, 1, 4, 28p (E). 2.3.

Jessen, A.

1922

Kortbladet Varde.

Danm. geol. Unders., I, 14, 105p (F).

1.1.2., 3.3., 4.3.2.1., 4.3.2.2., 4.4.

Jessen, A.

1925

Kortbladet Blaavandshuk.

Danm. geol. Unders., I, 16, 76p (F).

1.1.2., 3.3., 4.3.2.2., 4.4.

Jessen, A.

Klinten ved Halkhoved.

Danm. geol. Unders., IV, 2, 8, 26p (E).

1.2., 2.3., 4.3.2.1.

Jessen, A.

1931

Lønstrup Klint.

Danm. geol. Unders., II, 49, 142p (E).

2.3., 4.1.1., 4.3.2.

Jessen, A.

Demonstration af Israndlinier i Sønderjylland.

Meddr dansk geol. Foren., 8, 546

1935

3.3 .

Jessen, A.

1935

Geologisk Kort over Sønderjylland

1: 125000.

Danm. geol. Unders., Kort og tekst.

1.1.3.

Jessen, A.

1935

Kortbladet Haderslev.

Danm. geol. Unders., I, 17, 95p (F).

1.1.3., 1.2., 3.3., 3.4., 4.1.1., 4.3.2., 4.4., 4.5.

Jessen, A. 1936

Vendsyssels Geologi.

Danm. geol. Unders., V, 2, 195p

1.1.1., 3.2., 3.3., 3.4., 4.3.2., 4.3.2.1., 4.4., 4.5 . 
Jessen, A.

Kortbladet Sønderborg.

Danm. geol. Unders., I, 20, 91p (F).

1.1.3., 2.3., 3.2., 3.3., 3.4., 4.4., 4.5.

Jessen, K. og V. Milthers

1928

Stratigraphical and Paleontological Studies of Interglacial Fresch-water Deposits in Jutland and Nortwest Germany.

Danm. geol. Unders., II, 48, 379p 1.2 .

Johnsson, G.

1951

Studier över hällskulpturen på Bornholm.

Meddr dansk geol. Foren., 12, 67-82 (E).

1.1.7., 4.2.

Johnstrup, F.

1875

De geognostiske Forhold i Jylland.

Tidsskr. for Landøkonomi, København, $1-31$.

2.1., 3.1., 3.3., 4.1.1., 4.3.2.2.

Johnstrup, F.

1882

Nogle Iagttagelser over Glacialphænomenerne og Cyprina-Leret i Danmark.

Indbydelsesskrift til Universitets Fest, København, 1-74.

4.2., 4.3.2.2.

Johnstrup, F.

1882

Om de geologiske Forhold i den nordlige

Del af Vendsyssel.

Indbydelsesskrift til Universitets Aarsfest, København, 1-43.

1.1.1., 2.3., 4.3.2.2.

Johnstrup, F.

1882

Oversigt over de geognostiske Forhold i

Danmark.

V. Falbe Hansen og W. Scharling (eds),

Danmarks Statistik. 1, 31-83, København

2.1., 3.1.

Knattrup, N.

1955

Markens og strandens sten.

Natur og Museum, Århus, 4, 2, 1-14.

4.3.2.2.

Konradi, P. B.

1973

Foramineferas in some Danish glacial deposits.

Bull. geol. Instn Univ. Upsala, 5, 173175.

4.5 .
Konradi, P. B.

1974

se Petersen, K. Strand og P. B. Konradi

Krüger, J.

1969

Landskabsformer i sydlige Sjælland.

Geogr. Tidsskr., 68, 105-212 (E).

1.1.5., 2.3., 3.1., 3.2., 3.3., 3.4., 4.1.2., 4.2., 4.3.2.1., 4.3.2.2.

Krüger, J.

1970

Till fabric in relation to direction of ice movement.

Geogr. Tidsskr., 69, 133-170 (D).

3.2., 4.1.2., 4.2.

Krüger, J.

1974

Traditionelle ledeblokkes egnethed til brug i kvantitative analyser.

Dansk geol. Foren. Årsskrift 1973, 152 161.

4.3.2.2.

Liboriussen, $\mathbf{J}$.

1972

Fabric-studier af smeltevandsgrus og moræneler i den nordlige del af kortbladet Randers.

Dansk geol. Foren. Årsskrift 1971, 31-35. 1.1.2., 4.1.2.

Madirazza, I.

1969

se Gry, H., E. Heller og I. Madirazza

Madsen, E.

1968

En arkæologisk-geologisk unders øgelse af klinten ved Ejby Bro, Isefjord.

Meddr dansk geol. Foren., 18, 33-45 (E). 1.2 .

Madsen, V.

Istidens Foraminiferer i Danmark og Holsten.

Meddr dansk geol. Foren., 1, 2, 1-229. 4.5.

Madsen, $\mathrm{V}$.

1897

Kortbladet Samsø.

Danm. geol. Unders., I, 5, 87p

1.1.2., 4.3.2.1., 4.3.2.2.

Madsen, $\mathrm{V}$.

1897

se Ussing, N. V. og V. Madsen

Madsen, V. 1899

Om inddelingen af de danske Kvartærdannelser.

Meddr dansk geol. Foren., 1, 5, 1-22.

1.2., 4.3.2.2. 
Madsen, V.

1900

Kortbladet Bogense.

Danm. geol. Unders., I, 7, 112p (F).

1.1.4., 4.1.1., 4.3.2.1., 4.4., 4.5.

Madsen, V., V. Nordmann,

1900

K. I. V. Steenstrup og E. Østrup

Leda pernula Leret ved Selbjerggaard i Vester Hanherred.

Meddr dansk geol. Foren., 1, 6, 1-18.

1.2 .

Madsen, V.

1902

Kortbladet Nyborg.

Danm. geol. Unders., I, 9, 182p (F).

1.1.4., 3.4., 4.3.2.1., 4.4.

Madsen, V.

1903

Om den glaciale, isdæmmede $\mathrm{S} \emptyset$ ved

Stenstrup paa Fyn samt om Dannelsen af

Teglværksleret i Stenstrup-Egnen.

Danm. geol. Unders., II, 14, 86p (F).

1.1.4., 3.3., 4.4.

Madsen, V., V. Nordmann og

1908

N. Hartz

Eem-Zonerne.

Studier over Cyprinaleret og andre

Eem-Aflejringer i Danmark,

Nord-Tyskland og Holland.

Danm. geol. Unders., II, 17, 302p (F).

1.2., 2.3., 4.3.2.1., 4.4.

Madsen. V., V. Hintze,

V. Nordmann og E. M. Nørregaard

Om Aarsagen til Dislokationerne i vore

Klinter.

Meddr dansk geol. Foren., 4, 433-442.

2.3.

Madsen, V.

1916

Ristinge Klint.

Danm. geol. Unders., IV, 1, 2, 32p (F).

2.3., 4.3.2.1.

Madsen, $\mathrm{V}$.

1918

Kvartære Dislokationer.

Skand. Naturforskermøde. Kristiania 1916. Forh., 421-428.

2.3 .

Madsen, V.

1921

Terrainformerne paa Skovbjerg Bakkeø.

Danm. geol. Unders., IV, 1, 12, 24p (F).

1.1.2., 3.3., 4.4 .

Madsen, V.

1931

Ledeblokke og Israndsstadier i det cen- trale Danmark.

(Diskussion. Se Milthers, V. 1931 og

1931)

Meddr dansk geol. Foren., 8, 140-141.

1.1.2., 3.3.

Madsen, V. og V. Nordmann 1940

Kvartæret i Røgle Klint ved Lillebelt.

Danm. geol. Unders., II, 58, 142p (F).

1.2., 2.3., 4.3.2.1.

Madsen, $V$.

se Gry, H., K. Hansen, V. Madsen og V.

Nordmann

Madsen, $\mathrm{V}$.

1942

Røgle Klint, et naturligt Profil gennem en eocæn Horst og dens kvartære Forland. Naturens Verden, 219-232.

2.3 .

Marcussen, I.

1973

Stones in Danish tills as a stratigraphical tool - a review.

Bull. geol. Instn Univ. Upsala, 5, 177181.

4.3.2.1., 4.3.2.2.

Marcussen, I.

1973

Studies on flow till in Denmark.

Boreas, 2, 213-231.

2.2., 4.1.1., 4.2.

Marcussen, I.

1974

Stentællingsmetoden, ledeblokanalysen og glacialstratigrafi - En kritisk vurdering. Dansk geol. Foren. Årsskrift 1973, 20-42 (E).

4.3.2.1., 4.3.2.2.

Mertz, E. L.

1926

Metoder til Undersøgelse af Lerets fysiske Egenskaber.

Danm. geol. Unders., II, 44, 67p (E).

5.

Mertz, E. L.

1937

Geologiske Profiler gennem danske Sunde og Fjorde; med nogle Bemærkninger om dertil knyttede geotekniske Forhold.

Danm. geol. Unders., II, 60, 143p (F).

1.2., 4.1.1., 4.4., 5.

Mertz, E. L. 1949

Vekselvirkningen mellem Geologi og Geoteknik. 
Danm. geol. Unders., III, 29, 49p (E).

4.1.1., 5 .

Meyn, L.

1881

Geologische-Uebersichtskarte der Provinz Schleswig-Holstein. 1: 300000

K. Preuss. geologischen Landesanstalt

1.1.3.

Milthers, K.

Landskabets Udformning mellem Alheden og Limfjorden.

Danm. geol. Unders., II, 56, 36p (G).

1.1.2., 3.3.

Milthers, $\mathrm{K}$.

1935

se Bornebusch, C. H. og K. Milthers

Milthers, K.

1937

Indlandsisens Moræner omkring København.

Naturens Verden, 21, 289-301.

1.1.5., 3.1., 3.3.

Milthers, $\mathrm{K}$.

1941

Stenene og det danske Landskab.

Dansk Natur-Dansk Skole, København., $59 \mathrm{p}$

Samme udgivet i 1963 i København

4.3.2.2.

Milthers, K.

1941

Systematisk Eftersøgning af Brunkul.

Geogr. Tidsskr., 44, 100-117.

1.1.2.

Milthers, $\mathrm{K}$.

Erosionsformer i Midtjyllands Tertiæroverflade.

Meddr dansk geol. Foren., 10, 101-107. 1.1.2., 3.1.

Milthers, $\mathrm{K}$.

Ledeblokke og Landskabsformer i Danmark.

(Påfølgende diskussion se Andersen, S.

A. 1945 og Milthers, K. 1945)

Danm. geol. Unders., II, 69, 137p (E).

1.1., 1.2., 3.3., 4.3.2.2.

Milthers, K.

1945

Danmarks Overflade dannes.

Danmark, 1-10.

1.1.

Milthers, K.

1945

Om Ledeblokkenes Spredning.

(Diskussion. Se Andersen, S. A. 1945 og

Milthers, K. 1942)
Meddr dansk geol. Foren., 10, 609-612 og 614-615.

4.3 .

Milthers, K.

1946

Nogle Betragtninger over Isens Tilførselsveje til Danmark.

Geol. For. Stock. Forh., 68, 479-481.

4.3.2.2.

Milthers, $\mathrm{K}$.

1955

Landskabsformerne i en Del af Nordsjælland.

Dansk Natur - Dansk Skole, 16-21.

3.1., 3.3., 3.4.

Milthers, $\mathrm{K}$.

1959

Kortbladene Fåborg, Svendborg og Gulstav.

A: Kvartære aflejringer.

Danm. geol. Unders., I, 21A, 112p (E).

1.1.4., 2.1., 3.1., 3.2., 3.3., 4.4.

Milthers, V.

1899

Norske Blokke paa Sjælland.

Meddr dansk geol. Foren., 1, 5, 49-64. 4.3.2.2.

Milthers, V.

Tellina calcaria Leret ved Høve i Odsherred.

Meddr dansk geol. Foren., 1, 6, 37-44.

1.2 .

Milthers, V.

1900

se Rørdam, K. og V. Milthers

Milthers, V.

1901

Skurstriberne ved Fakse.

Meddr dansk geol. Foren., 2, 8, 1-20.

4.2.

Milthers, V.

1905

Woher stammen die sogenannten

"Rödö"-Quarzporphyrgeschiebe im baltischen Diluvium?

Meddr.dansk geol.Foren., 2,11,113- 118 . 4.3.2.

Milthers, V

1906

Er Næstved-Mogenstrup Aasen en Endemoræne?

Meddr dansk geol. Foren., 2, 12, 89-90. 3.3 .

Milthers, V.

1907

Vendsyssels ældre Yoldialer og den glaciale Lagfølge i Jylland. 
Meddr dansk geol. Foren., 3, 1-12.

1.1.1., 4.5.

Milthers, V.

Kortbladene Faxe og Stevns Klint.

Danm. geol. Unders., I, 11, 291p (F).

1.1.5., 2.1., 3.1., 3.3., 4.1.1., 4.2.,

4.3.2.2., 4.4.

Milthers, V.

1909

Scandinavian Indicator-Boulders in the Quaternary deposits.

Danm. geol. Unders., II, 23, 153p (D). 4.3.2.2.

Milthers, $\mathrm{V}$.

1910

se Jessen, A., V. Milthers, V. Nordmann, N. Hartz og A. Hesselbo

Milthers, V.

1913

Ledeblokke i de skandinaviske Nedisningers sydvestlige Grænseegne.

Meddr dansk geol. Foren., 4, 115-182 (G).

4.3.2.2.

Milthers, V. og Th. Claudi West

1913

Viborg Egnens Mergellag, deres geologiske Omgivelser og deres Udnyttelse.

Danm. geol. Unders., III, 9, 70p

1.1.2., 3.3., 4.4 .

Milthers, V.

1914

Mergel og Kalk i det nordvestlige Jylland.

Danm. geol. Unders., III, 11, 24p

1.1.1., 4.4.

Milthers, V.

1916

Mergelaflejringerne i Hammerum Herred.

Danm. geol. Unders., III, 13, 21p

1.1.2., 4.4.

Milthers, V.

se Grönwall, K. A. og V. Milthers

Milthers, V.

1916

Mergelen i Holstebro Egnen.

Danm. geol. Unders., III, 15, 18p

1.1.2., 4.4.

Milthers, V.

Grundlinier i Isens Bortsmeltning fra

Sjælland.

Skand. Naturforskermøde. Kristiania

1916. Forh., 410-421.

1.1.5., 3.3.

Milthers, V.

1919

Mergelen i Djursland.
Danm. geol. Unders., III, 18, 41p

1.1.2., 4.4.

Milthers, V.

Jordbundsforholdene omkring Overlund ved Viborg.

Danm. geol. Unders., III, 19, 20p

1.1.2., 4.1.1., 4.4

Milthers, $\mathrm{V}$.

1923

Kalk og Mergel paa Sjælland.

Danm. geol. Unders., III, 23, 80p

1.1.5., 4.4.

Milthers, V.

1925

Danmarks Jord.

K. Hansen (ed.):

Det danske Landbrugs Historie,

København, 74p

4.3.

Milthers, V.

1925

Kortbladet Bække.

Danm. geol. Unders., I, 15, 175p (F).

1.1.2., 3.3., 4.3.2.1., 4.3.2.2., 4.4.

Milthers, V.

1927

On the so-called gothi-glacial limit in Denmark.

Geogr. Annlr., 3, 162-172.

3.3.

Milthers, V.

1928

Glacialgeologiske Retningslinjer i

Odense Egnen.

Danm. geol. Unders., IV, 2, 4, 24p

1.1.4., 2.1., 3.3.

Milthers, V.

1928

se Jessen, K. og V. Milthers

Milthers, V.

1929

Betydningsfulde Forekomster af Basaltblokke i Jylland.

Meddr dansk geol. Foren., 7, 309-316.

1.1., 4.3.2.2.

Milthers, V.

Lidt om Landskabet omkring Brænde Aa paa Fyn.

Geogr. Tidsskr., 32, 217-221.

3.3., 3.4.

Milthers, V.

1930

Bornholms Geologi.

Danm. geol. Unders., V, 1, 140p

1.1.7., 3.3., 4.2., 4.3.2.2. 
Milthers, V.

1931

Israndens Tilbagerykning fra Østjylland til Sjælland-Fyn, belyst ved Ledeblokke.

(Påfølgende diskussion se Madsen, V. 1931 og Milthers, V. 1931)

Meddr dansk geol. Foren., 8, 1-70.

Samme udgivet 1932 i Danm. geol. Unders., IV, 2, 9, 70p (G).

1.1., 3.3., 4.3.2.2.

Milthers, V.

Ledeblokke og Israndsstadier i det centrale Danmark.

(Diskussion. Se Madsen, V. 1931 og Milthers, V. 1931)

Meddr dansk geol. Foren., 8, 139-142.

1.1.2., 3.3.

Milthers, V.

Die Verteilung skandinavischer Leitgeschiebe im Quartär von Westdeutschland. Abh. preuss. geol. Landesanst. N. F., $156,1-74$.

4.3.2.2.

Milthers, V.

1935

Nordøstsjællands Geologi.

Danm. geol. Unders., V, 3, 192p

1.1.5., 2.1., 2.2., 2.3., 3.1., 3.3., 3.4., 4.3.2.2.

Milthers, V.

1936

Geschiebeuntersuchungen und Glazialstratigraphie.

Z. dt. geol. Ges., 88, 115-120.

4.3.2.2.

Milthers, V.

1939

Beiträge skandinavischer Leitgeschiebe für die Bestimmung der Vereisungsgrenzen.

Z. dt. geol. Ges., 91, 261-272.

4.3.2.2.

Milthers, V.

1939

Kortbladet Brande.

Danm. geol. Unders., I, 18, 162p (F).

1.1.2., 3.3., 3.4., 4.3.2.1.

4.3.2.2., 4.4.

Milthers, V.

1940

Kortbladet Vissenbjærg.

Danm. geol. Unders., 1, 19, 143p (F).

1.1.4., 3.3., 4.3.2.2., 4.4 .

Milthers, V.

1943

Nordvestsjællands Geologi.
Danm. geol. Unders., V, 6, 185p

1.1.5., 2.1., 3.1., 4.3.2.2.

Milthers, V.

1948

Det danske Istidslandskabs Terrænformer og deres Opstaaen.

Danm. geol. Unders., III, 28, 233p (E).

1.1., 3.1., 3.2., 3.3., 3.4.

Milthers, V.

1948

Et Tilbageblik over Strejftog efter Ledeblokke gennem 40 Aar 1989-1937.

Meddr dansk geol. Foren., 11, 247-305 (E).

4.3.2.2.

Milthers, V.

1948

Fund af Basaltblokke i Sydjylland og Sønderjylland.

Meddr dansk geol. Foren., 11,

267-268.

4.3.2.2.

Milthers, V.

1955

Et vestjysk istidsområde.

Meddr dansk geol. Foren., 13, 61-78.

1.1.2., 4.3.2.2.

Milthers, V.

1957

Sydvestjyllands glaciale lagforhold.

Meddr dansk geol. Foren., 13, 206-216

(E).

1.1.2., 4.3.2.2.

Milthers, V.

1960

Stenenes vandringer i Istiden.

Naturens Verden, 338-346.

4.3.2.2.

Münnich, G.

1936

Quantitative Geschiebeprofile aus Dänemark und Nordostdeutschland mit besonderer Berücksichtigung Vorpommerns.

Abh. geol.-paleont. Inst. Greifswald, 15, $1-52$.

1.2., 4.3.2.1.

Munthe, $\mathrm{H}$.

1889

Iakttagelser öfver qvartära aflagringar på Bornholm.

Geol. For. Stockh. Forh., 11, 274-287.

1.1.7., 4.3.2.2.

Møller, J. M.

1928

Træk af Aarhusegnens Geologi.

Jydsk Foren. for Naturvidenskab i Aarhus, $21-40$.

3.3 . 
Møller, M.

1927

Fra Aarhus-Dalen til Horsens Fjord.

Meddr dansk geol. Foren., 7, 151-164.

1.1.2., 3.3.

Nielsen, A. V.

1961

Lind $\varnothing$, et af Keld Milthers sidste kvartærgeologiske arbejdsfelter.

Meddr dansk geol. Foren., 14, 453- 454 1.1.4., 4.1.2.

Nielsen, A. V.

1961

se Hansen, S. og A. V. Nielsen

Nielsen, O. Bjørslev

1973

Eocæne aflejringer i Ølst-området og deres indpasning $\mathrm{i}$ områdets kvartærgeologi.

Dansk geol. Foren. Årsskrift 1972, 100 110 .

1.1.2., 2.3.

Nordmann, $\mathrm{V}$.

1900

se Madsen, V., V. Nordmann, K. I. V.

Steenstrup og E. Østrup

Nordmann, $\mathrm{V}$.

1908

se Madsen, V., V. Nordmann og N. Hartz

Nordmann, V.

1910

se Jessen, A., V. Milthers, V. Nordmann,

N. Hartz og A. Hesselbo

Nordmann, V.

1915

se Madsen, V., V. Hintze, V. Nordmann

og E. M. Nørregaard

Nordmann, $\mathrm{V}$.

1918

Om Inddelingen af Nordeuropas Kvartær paa Grundlag af Iagttagelser i Danmark. Skand. Naturforskerm øde. Kristiania 1916. Forh., 414-419.

1.2 .

Nordmann, V.

1927

Israndslinier paa Kortbladet "Fredericia".

Meddr dansk geol. Foren., 7, 171-175.

1.1.2., 3.3.

Nordmann, V.

1927

Træk af Lollands Geologi.

Lolland-Falster historiske Samfund, Aarbog, 15, 1-15.

1.1.6.

Nordmann, V.

1928

Ekskursion til Vejle-Fredericia egnen. (Ekskursionsberetning)
Meddr dansk geol. Foren., 7, 239-246.

1.1.2., 2.3., 3.3.

Nordmann, $\mathrm{V}$.

1928

La position stratigraphique des Dépôts d'Eem.

Danm. geol. Unders., II, 47, 81p (D).

4.3.2.1.

Nordmann, V. (ed.)

1928

Oversigt over Danmarks Geologi.

Danm. geol. Unders., V, 4, 208p (E/F/G) 1.1., 1.2., 3.3.

Nordmann, $\mathrm{V}$.

1935

De geologiske Forhold langs Kongeaadalen.

Historisk Samfund for Ribe amt, 8, 597616.

1.1.3.

Nordmann, V.

1940

se Madsen, V. og V. Nordmann

Nordmann, $\mathrm{V}$.

se Gry, H., K. Hansen, V. Madsen og V.

Nordmann

Nordmann, V.

1943

Himmerlands Tilblivelse.

Turistforeningen for Danmark.

Aarbog, 9-23.

3.3.

Nordmann, $\mathrm{V}$.

1943

Tønder gennem Tiderne.

Historisk Samfund for Sønderjylland, 3, 7-31.

1.1.3.

Nordmann, $\mathrm{V}$.

1944

Den fredede Røgle Klint.

Danmark, 4, 600-606.

2.3.

Nordmann, V.

1947

se Hansen, S., V. Nordmann og

Th. Sorgenfrei

Nordmann, V.

1950

se Hansen, S. og V. Nordmann

Nordmann, V.

Kortbladet Fredericia.

A: Kvartære aflejringer.

Danm. geol. Unders., I, 22A,

$125 \mathrm{p}(\mathrm{E})$.

1.1.2., 3.1., 3.3., 3.4., 4.4. 
Nørregaard, E. M.

1912

Bovbjerg - Profilet.

Meddr dansk geol. Foren., 4, 47-54.

4.1.2., 4.3.2.1.

Nørregaard, E. M.

1915

se Madsen, V., V. Hintze, V. Nordmann og E. M. Nørregaard

Penck, A.

Die Geschiebeformation Norddeutschlands.

Z. dt. geol. Ges., 31, 117-203.

1.2 .

Petersen, F. Schausen

1958

Landskabet.

Huhle, R. (ed.), Bogen om Himmerland, Aabenraa. 7-43.

1.1.1., 3.1., 3.3.

Petersen, K. Strand

1973

Tills in dislocated drift deposits on the Røsnaes peninsula, northwestern Sjaelland, Denmark.

Bull. geol. Instn Univ. Upsala, 5, 41-49. 2.3., 4.1.1., 4.3.2.1.

Petersen, K. Strand og A. Buch 1974

Dislocated tills with Paleogene and Pleistocene marine beds. Tectonics, Lithology, macro - and microfossils.

Danm. geol. Unders. Årbog 1973, 63-91

(D).

2.3., 4.1.1., 4.3.2.1., 4.5.

Petersen, K. Strand og

1974

P. B. Konradi

Lithologisk og palæontologisk beskrivelse af profiler i Kvartæret på Sjælland.

Dansk geol. Foren. Årsskrift 1973, 47-56.

1.1.5., 2.3., 4.1.1., 4.3.1., 4.3.2.1., 4.5.

Pingel, V. 1886

Dansk Geologi.

Tilskueren, 478-490 og 629-642.

2.1 .

Rasmussen, H. Wienberg

1965

Strukturer dannet ved jordflydning, udglidning og issø-tapning i kvartære smeltevandsaflejringer.

Meddr dansk geol. Foren., 15, 470-485

(E).

2.2 .
Rasmussen, H. Wienberg

1967

Undersøgelser og tolkninger af dislocerede issøbakker.

Meddr dansk geol. Foren., 17, 37-57 (E). 2.3., 3.4 .

Rasmussen, L. Aabo 1974

Om morænestratigrafi i det nordlige Øresundsområde.

Dansk geol. Foren. Årsskrift 1973, 132139 (E).

1.1.5., 2.2., 2.3., 4.1.2.

Ravn, J. P. J. 1911

Om en Spalte i Kalkstenen ved Faxe.

Meddr dansk geol. Foren., 3, 513-526. 2.3 .

Rosenkrantz, A.

1944

Nye Bidrag til Forstaaelsen af Ristinge Klints Opbygning.

Meddr dansk geol. Foren., 10, 431-435.

2.3 .

Rørdam, K. 1893

Kortbladene Helsingør og Hillerød.

Danm. geol. Unders., I, 1, 110p (F).

1.1.5., 4.1.1., 4.3.2.1., 4.3.2.2., 4.5., 5.

Rørdam, K.

1894

Geologisk-agronomiske Unders $\emptyset$ gelser ved Lyngby Landboskole og Brede Ladegaard.

Danm. geol. Unders., II, 3, 49p

4.1.1., 4.4.

Rørdam, K. og C. Bartholin

1897

Om Forekomsten af Juraforsteninger i løse Blokke i Moræneler ved København.

Danm. geol. Unders., II, 7, 16p

4.3.2.2.

Rørdam, K.

1899

Kortbladene Kjøbenhavn og Roskilde.

Danm. geol. Unders., I, 6, 108p (F).

1.1.5., 4.4.

Rørdam, K. og V. Milthers

1900

Kortbladene Sejrø, Nykøbing, Kalundborg og Holbæk.

Danm. geol. Unders., I, 8, 143p (F).

1.1.5., 2.1., 2.2., 2.3., 3.1., 3.2., 3.3., 4.2., 4.3.2.1., 4.3.2.2., 4.5.

Rørdam, K.

1909

Geologi og Jordbundslære.

3 bd, København.

1.1 . 
En Belægning af isskurede Blokke i Nymølle Grusgrav ved Hedehusene.

Meddr dansk geol. Foren., 2, 143-144. 4.2 .

Sarauw, G. F. L. 1912

Vore store Sten (Vandreblokke), deres Registrering og Fredning.

Meddr dansk geol. Foren., 4, 111-112. 4.3.2.

Simonsen, K.

1927

Sorøegnens Geologi.

Aarbog for Historisk Samfund for Sor $\varnothing$ Amt, 15, 22-35.

3.3 .

Sjørring, S.

1973

Some problems in the till stratigraphy of the northeastern part of Sjaelland.

Bull. geol. Instn Univ. Upsala, 5, 31-35. 1.1.5., 2.3., 3.3., 4.3.2.1.

Sjørring, S.

1974

Klinterne ved Hundested.

Dansk geol. Foren. Årsskrift 1973, 108117 (E).

2.2., 2.3., 4.3.2.2.

Slater, G.

1926

The structure of the disturbed deposits of Möens klint and Lönstrup, Denmark.

J. Sci. Trans. Oxford., 21-22.

2.3.

Slater, G.

The disturbed glacial Deposits in the Neighbourhood of Lønstrup, near Hjørring, North Denmark.

Trans. R. Soc. Edinb., 55, 303-315. 2.3 .

Slater, G.

1927

The structure of the disturbed deposits of Møens klint, Denmark.

Trans. R. Soc. Edinb., 55, 289-302.

2.3 .

Smed, P. 1962

Studier over den fynske øgruppes glaciale landskabsformer.

(Påfølgende diskussion se Andersen, S.

A. 1963 og Smed, P. 1963)

Meddr dansk geol. Foren., 15, 1-74 (E).

1.1.4., 2.1., 3.1., 3.2., 3.3.
Gensvar til S. A. Andersen.

(Diskussion. Se Andersen, S. A. 1963 og Smed, P. 1962)

Meddr dansk geol. Foren., 15, 228-229.

1.1.4.

Smed, P.

1963

Israndsliniekort.

(Påfølgende diskussion se Andersen, S.

A. 1965)

Biologi og Geografi, 4, 66-67.

3.3.

Sorgenfrei, Th.

1947

se Hansen, S., V. Nordmann

Steensby, H. P.

1925

Om de danske Öers geografiske Udvikling i senglacial tid.

Geogr. Annlr., 23-80.

3.3.

Steenstrup, K. I. V.

1900

se Madsen, V., V. Nordmann, K. I. V. Steenstrup og E. Østrup

Struck, R.

1909

Übersicht der geologischen Verhältnisse Schleswig-Holsteins.

Festchrift zur Begrüssung, des 17. Deutschen Geographentages. Lübeck, 169p

1.1.3.

Struck, R.

1932

Die Oberflächenformen Schleswig-Holsteins und ihre Entstehung.

Lübeck. 31p

1.1.3.

Sørensen, R. P.

1939

Landskabsformer.

I: Sørensen, R. P. (ed.), Bogen om Bov Sogn, skrevet af Mænd i Sognet.

Padborg. 7-27.

1.1.3.

Sørensen, R. P.

1963

Sønderjyske Landskaber.

Faglig Læsning, 48, København. 32p

1.1.3.

Thamdrup, $\mathrm{K}$.

1970

Klinten ved Mols Hoved. En kvartærgeologisk undersøgelse.

Dansk geol. Foren. Årsskrift 1969, 2-8 (E). 2.3. 
Ussing, N. V. og V. Madsen

1897

Kortbladet Hindsholm.

Danm. geol. Unders., I, 2, 87p (F).

1.1.4., 4.2., 4.3.2.1., 4.3.2.2.

Ussing, N. V.

Geologi og Overflade forhold.

I: J. P. Trap, Kongeriget Danmark, 1, 3-22, København.

1.1 .

Ussing, N. V.

1903

Om Jyllands Hedesletter og Teorierne for deres Dannelse.

K. danske Vidensk. Selsk. Skr., 2, 99-165

(F).

1.1., 3.3.

Ussing, N. V.

1903

Om et nyt Findested for marint Diluvium ved Hostrup i Salling. Vidensk.

Meddr dansk naturh. Foren., 111-123. 1.2., 4.3.

Ussing, N. V.

1907

Om Floddale og Randmoræner i Jylland.

K. danske Vidensk. Selsk. Skr., 4, 160213 (F).

1.1., 2.3., 3.3.

Ussing, N. V.

1913

Danmarks Geologi i almenfatteligt omrids. 3. Ed.

Danm. geol. Unders., III, 2, 372p

1.1 .

Wennberg, G.

1943

Eisströme über Schonen während der letzten Eiszeit.

Acta Univ. lund, NF, avd. 2, 39, 3, 28p 1.1 .

Wennberg, G.

1949

Differentialrörelser i Inlandsisen.

Sista Istiden i Danmark, Skåne och Östersjön.

Meddn Lunds geol.-min. Instn., 114, 201p

1.1.4., 1.1.5., 1.1.7., 2.3., 4.3.2.2.

Wennberg, G.

1951

Über den Geschiebetransport im Inlandeis.

Schr. naturw. Ver. Schlesw.-Holst., 25, 108-114.

4.3.2.2.
Werth, E.

1907

Dänemark und die Eiszeit.

Aus der Natur, 1-5.

1.1 .

Werth, E.

1907

Studien zur glazialen Bodengestaltung in den skandinavischen Ländern.

Z. Ges. Erdk. Berl., 27-43, 87-101.

3.2., 3.3.

West, Th. Claudi

se Milthers, V. og Th. Claudi West

Woldstedt, P.

1913

Beiträge zur Morphologie von Nordschleswig.

Mitt. geogr. Ges. naturh. Mus. Lübeck, $2,26,1-70$.

1.1.3., 3.3.

Woldstedt, P.

1926

Probleme der Seenbildung in Norddeutschland.

Zeit. Gesell. Erdkunde, Berlin, 103-124.

1.1.3., 3.3.

Woldstedt, P.

1930

Die Gliederung des Nordeuropäischen

Diluviums. Nordmann, V (ed.), Compte

Rendu de la Réunion géologique internationale a Copenhague 1928.

Danm geol. Unders, 209-224.

1.1.3.

Woldstedt, P.

1935

Geologisch-morphologischen Übersichtskarte des norddeutschen Vereisungsgebietes. 1: 1.500000 .

Preuss. geologischen Landesanstalt. Kort og tekst.

1.1.3.

Wolf, W.

1913

Geologisch-agronomische Karte der Umgegend von Apenrade nebst Erläuterungen.

K. geol. Landesanstalt. Berlin, 22p

4.3.2.

Wolf, W.

1922

Erdgeschichte und Bodenaufbau

Schleswig-Holsteins.

Hamburg 163p

1.1.3. 
Wolf, W. und H-L. Heck

Erdgeschichte und

Schleswig-Holsteins.

Hamburg 194p

1.1.3.

$\emptyset$ dum, H.

1927

Bemærkninger om Vestgrænsen for den sidste Nedisning i Nordslesvig.

Meddr dansk geol. Foren., 7, 170-171. 1.1.3., 3.3.

Ødum, H.

1933

Marint Interglacial paa Sjælland, Hven, Møn og Rügen.

Danm. geol. Unders., IV, 2, 10, 44p (G). 1.1.5., 2.3.

$\varnothing$ dum, $\mathrm{H}$.

1937

Jordlag og Landskabsformer. Clausen, H. V. og H. Ødum (eds), Nordslesvig, Min Hjemstavn, nr. 10, 1-18, København.

1.1.3.
Flintkonglomeratet i Jylland.

Meddr dansk geol. Foren., 18, 1-32 (E). 4.3.2.

Ødum, $\mathrm{H}$.

1969

Kvartæret omkring Hobro.

Danm. geol. Unders., IV, 4, 10, 23p (G).

1.1.2., 3.3., 3.4., 4.3.2.

Østrup, E.

1900

se Madsen, V., V. Nordmann, K. I. V. Steenstrup og E. Østrup 
This book is the most complete list of books, papers etc. about Danish Moraine Deposits. It will serve as an unvaluable help for those interested in Danish Quaternary Geology.

Denne bog er den hidtil mest fuldstændige bibliografi over bøger, afhandlinger, artikler m.v. om moræner i Danmark. Den vil være en uvurderlig hjælp for alle, der beskæftiger sig med Danmarks kvartær geologi. 